\title{
Clitocybe nuda Activates Dendritic Cells and Acts as a DNA Vaccine Adjuvant
}

\section{Mei-Hsing Chen, ${ }^{1}$ Wei-Sung $\mathrm{Li},{ }^{1}$ Yun-Sheng Lue, ${ }^{1}$ Ching-Liang $\mathrm{Chu},{ }^{2}$ I-Hong Pan, ${ }^{3}$ Ching-Huai Ko, ${ }^{3}$ Der-Yuan Chen, ${ }^{4,5,6}$ Ching-Hsiung Lin, ${ }^{7}$ Sheng-Hao Lin, ${ }^{4,7}$ Chih-Peng Chang, ${ }^{8}$ and Chi-Chen Lin ${ }^{4,9}$}

${ }^{1}$ Plant Pathology Division, Taiwan Agricultural Research Institute (TARI), Council of Agriculture (COA), Executive Yuan, Wufeng 413, Taiwan

${ }^{2}$ Graduate Institute of Immunology, National Taiwan University, Taipei 112, Taiwan

${ }^{3}$ Biomedical Technology and Device Research Laboratories, Industrial Technology Research Institute, Hsinchu 300, Taiwan

${ }^{4}$ Institute of Biomedical Science, National Chung-Hsing University, Taichung 402, Taiwan

${ }^{5}$ Faculty of Medicine, National Yang-Ming University, Taipei 112, Taiwan

${ }^{6}$ Division of Allergy, Immunology and Rheumatology, Taichung Veterans General Hospital, Taichung 407, Taiwan

${ }^{7}$ Division of Chest Medicine, Department of Internal Medicine, Changhua Christian Hospital, Changhua 500, Taiwan

${ }^{8}$ Department of Microbiology and Immunology, College of Medicine, National Cheng Kung University, Tainan 701, Taiwan

${ }^{9}$ Department of Medical Research and Education, Taichung Veterans General Hospital, Taichung 407, Taiwan

Correspondence should be addressed to Chi-Chen Lin; lincc@dragon.nchu.edu.tw

Received 8 March 2013; Revised 25 May 2013; Accepted 1 June 2013

Academic Editor: Andreas Sandner-Kiesling

\begin{abstract}
Copyright (C) 2013 Mei-Hsing Chen et al. This is an open access article distributed under the Creative Commons Attribution License, which permits unrestricted use, distribution, and reproduction in any medium, provided the original work is properly cited.

This work represents the first evaluation of the effects of water extract of $C$. nuda (WE-CN), an edible mushroom, on murine bone marrow-derived dendritic cells (BMDCs) and the potential pathway through which the effects are mediated. Our experimental results show that WE-CN could induce phenotypic maturation of DCs, as shown by the increased expression of MHC and costimulatory molecules. In addition, it also induced the proinflammatory cytokines expression on DCs and enhanced both the proliferation and IFN- $\gamma$ secretion of allogenic T cells. Therefore, since WE-CN did not induce maturation of DCs generated from mice with mutated TLR-4 or TLR-2, suggesting that TLR4 and TLR2 might function as membrane receptors for WE-CN. Moreover, the mechanism of action of WE-CN may be mediated by increased phosphorylation of ERK, p38, and JNK mitogen-activated protein kinase (MAPK) and increased NF- $\kappa$ B p65 activity, which are important signaling molecules downstream of TLR-4 and TLR-2. Finally, coimmunization of mice with WE-CN and a HER-2/neu DNA vaccine induced a HER-2/neu-specific Th1 response that resulted in significant inhibition of HER-2/neu overexpressing mouse bladder tumor (MBT-2) growth. These data suggest that WE-CN induces DC maturation through TLR-4 and/or TLR-2 and that WE-CN can be used as an adjuvant in cancer vaccine immunotherapy.
\end{abstract}

\section{Introduction}

Dendritic cells (DCs) are professional antigen-presenting cells (APCs) that play a key role as immune sentinels by initiating T-cell responses and linking innate and adaptive immunity $[1,2]$. DCs are present at different stages of maturation in the circulation and in nonlymphoid and lymphoid organs. DCs reside in an immature form in peripheral nonlymphoid tissues, where they capture and process exogenous antigens [3]. Once activated, DCs migrate to the T-celldependent areas of secondary lymphoid organs, where they present antigenic peptides to T lymphocytes and stimulate naïve T-cell responses through cytokine signals, major histocompatibility complex- (MHC-) presenting Ag peptides and costimulatory molecules (e.g., CD40 and CD80). As key regulatory mediators of immune responses, DCs are being pursued for the development of potent new vaccines against cancer and infectious diseases $[4,5]$. In addition, the 
identification of materials that can modulate DC activation and function is an emerging field that can develop alongside DC immunobiology [6]. Natural or synthetic activators that promote DC activation may potentially be candidate adjuvants for application in immunotherapy and vaccination.

Growing evidence-based research has suggested benefits of consuming mushrooms as a functional food or through the use of extracted bioactive compounds as dietary supplements, immunomodulators (biological response modifiers), and adjuvant tumor therapy [7-10]. Numerous compounds have been isolated from mushrooms and have great potential for development as mushroom nutraceutical and pharmaceutical products. Among these compounds, water-soluble polysaccharides and proteoglycans, proteins, and various constituents of small molecular mass are considered to have immunomodulatory potential by regulating several types of immune cells that function in antitumor or antimicrobial activities, including dendritic cells, macrophages, cytolytic T cells, and NK cells [9-12].

Clitocybe nuda (also known as Lepista nuda, commonly known as blewits) is an edible woodland mushroom found in Europe, North America, Asia, and Australia [13]. Due to its special fragrance and delicate texture, C. nuda has been cultivated in France, Holland, Britain, and Taiwan. Several bioactive extracts from $C$. nuda have been found to exhibit antioxidant and antimicrobial properties [14-18], but few reports have described medicinal activities or health benefit in human disorders. To our knowledge, only three papers have shown that $C$. nuda extract affects cancer cells in vitro [19-21]. However, no studies have specifically reported immunologic effects of C. nuda.

Therefore, to study the effects of C. nuda on immune response and its potential cellular targets, we investigated whether C. nuda affects the maturation and functional properties of murine bone marrow-derived dendritic cells (BMDCs). Our findings demonstrate for the first time that water extract Clitocybe nuda (WE-CN) induces the phenotypic and functional maturation of BMDCs via ERK1/2, JNK, and p38 MAPK and the nuclear translocation of the NF$\kappa \mathrm{B}$ p65 subunit, in part, by the TLR- 4 and TLR-2 pathways. Significantly, WE-CN cotreatment enhanced the therapeutic efficacy of a HER-2/neu DNA vaccine against HER-2/neuoverexpressing tumors, suggesting that WE-CN could be a novel adjuvant and has potential application in cancer therapy and vaccination.

\section{Material and Methods}

2.1. Mice and Cell Cultures. Five- to eight-week-old specific pathogen-free female $\mathrm{C} 57 \mathrm{BL} / 6, \mathrm{C} 3 \mathrm{H} / \mathrm{HeN}$, and $\mathrm{C} 3 \mathrm{H} / \mathrm{HeJ}$ (TLR-4 mutant) mice were purchased from the National Laboratory Animal Center (Taipei, Taiwan). TLR-2 knockout mice were provided by Dr. Chih-Peng Chang (NCKU, Tainan, Taiwan). OT-I TCR transgenic mice were purchased from the Jackson Laboratory (Bar Harbor, ME, USA). OT-II TCR transgenic mice were provided by Dr. Clifford Lowell (UCSF, San Francisco, CA, USA). All mice were housed in the barrier facility at Taichung Veterans General Hospital (Taichung, Taiwan) in accordance with the Institutional Animal Care and Use Committee guidelines for animal experimentation, and all procedures were performed in accordance with the Institutional Animal Care and Use Committee guidelines for animal experimentation.

The MBT-2 murine bladder tumor cell line, derived from a carcinogen-induced bladder tumor in $\mathrm{C} 3 \mathrm{H}$ mice, has been described and is known to express high levels of p185 ${ }^{\text {neu }}[22]$. Mouse DCs were generated from bone marrow as previously described [23]. Bone marrow (BM) cells were flushed from the femurs and tibias of C57BL/6 mice, lyzed red blood cells with ammonium chloride, and then washed with PBS. BM cells were suspended in RPMI-1640 medium supplemented with $10 \%$ heat-inactivated fetal bovine serum, $100 \mathrm{U} / \mathrm{mL}$ penicillin G, $100 \mu \mathrm{g} / \mathrm{mL}$ streptomycin, $2 \mathrm{mM}$ L-glutamine, $20 \mathrm{ng} / \mathrm{mL}$ recombinant mouse granulocyte-monocyte colony-stimulating factor (Peprotech) and $20 \mathrm{ng} / \mathrm{mL}$ recombinant mouse IL-4 (Peprotech), and culturedin 24-well plates (5 $\times 10^{5}$ cells $\left./ \mathrm{mL}\right)$. Fresh medium was supplied every 2 days, and nonadherent cells were harvested on day 7 as immature DCs.

2.2. Preparation of Water Extract C. nuda. The fruiting bodies of C. nuda strain Tainung No. 1 were cultivated on compost and harvested by the Taiwan Agricultural Research Institute Mushroom Laboratory. After oven-drying, $30 \mathrm{~g}$ of the dried mushroom samples were milled and submitted to aqueous extraction under reflux $\left(40 \mathrm{x}\right.$ at $100^{\circ} \mathrm{C}$ for $\left.40 \mathrm{~min}\right)$. The aqueous extract was filtered over Whatman no. 1 paper, and the filtrate was evaporated to a small volume and lyophilized. The dry extracts were stored frozen at $-20^{\circ} \mathrm{C}$ until use. The crude extracts were resolubilized in MilliQ water at 4 different concentrations $(12.5,25,50$, and $100 \mu \mathrm{g} / \mathrm{mL})$. To remove endotoxins (lipopolysaccharides or LPS), the sample preparations were passed through an EndoTrap Blue column (Hyglos, Bernried, Germany). The level of endotoxin in the sample preparation was determined by a quantitative, chromogenic QCL-1000 Limulus amoebocyte lysate (LAL) assay (Cambrex Bio Science Walkersville, Inc., Walkersville, MD, USA) and was found to be $<0.1 \mathrm{ng} / \mathrm{mg}$ protein. Furthermore, to inhibit endotoxin activity, the samples were incubated on a rotator for 2 hours at $37^{\circ} \mathrm{C}$ with $10 \mu \mathrm{g} / \mathrm{mL}$ polymyxin $\mathrm{B}$.

2.3. In Vitro DC Activation. Immature DCs were cultured at a density of $1 \times 10^{6}$ cells/well in 24-well plates in medium alone or in the presence of $100 \mathrm{ng} / \mathrm{mL}$ LPS (Escherichia coli, serotype O26:B6 (Sigma St. Louis, MO, USA)), $1 \mu \mathrm{g} / \mathrm{mL}$ lipoteichoic acid (LTA, LTA; L2515, from Staphylococcus aureus, SIGMA, St. Louis, MO, USA), or WE-CN (0, 25, 50, or $100 \mu \mathrm{g} / \mathrm{mL}$ ) for $24 \mathrm{hr}$ (or $6 \mathrm{hr}$ for the TNF-alpha ELISA). The cells were then used for further immunophenotyping, the cytokine production assay, or the addition of T cells for DC-T coculture experiments.

2.4. Flow Cytometric Analysis of Surface Markers. After stimulation, DCs were harvested and stained with FITCconjugated mouse $\mathrm{CD}_{11 c^{+}}$or phycoerythrin- (PE-) conjugated anti-mouse CD40, anti-mouse CD80, anti-mouse CD86, anti-mouse MHC class I, anti-mouse MHC class II, or isotype-matched control mAbs (all from BioLegend, San Diego, CA, USA) for $45 \mathrm{~min}$ on ice $(1 \mu \mathrm{g} / \mathrm{mL}$ diluted in 
PBS/1.0\% FCS (v/v)). After washing with PBS, the fluorescent intensity was measured with a FACSCalibur flow cytometer (BD Biosciences), and the data were analyzed using WINMDI software (Scripps, La Jolla, CA, USA). The results are expressed in terms of the relative mean fluorescence intensity (MFI) on CD11c ${ }^{+}$gated conventional dendritic cells.

2.5. Cellular Morphology Analysis. The morphology of the DC cells was examined on day 6 and $24 \mathrm{~h}$ after LPS or WE$\mathrm{CN}$ stimulation using a phase contrast microscope and digital photography to record the images.

2.6. Cytokine Detection. To quantify the production of cytokines and chemokines, supernatants were collected from immature DCs propagated in the presence of LPS or WE-CN. After incubation, cytokines (mTNF-alpha, mIL-6, mIL12p70, and mIL-4) production by DCs was measured in the supernatants by sandwich ELISA assays according to the manufacturer's specifications (all from PeproTech, Rocky Hill, NJ, USA).

2.7. Allogenic Mixed Lymphocyte Reaction. Mouse T cells were isolated from naïve C57BL/6 mice spleens using EasySep Mouse T Cell Enrichment Kitseparation, respectively, according to the manufacturer's protocol (Stem Cell Technologies, Grenoble, France). Immature DCs were stimulated with LPS $(100 \mathrm{ng} / \mathrm{mL})$ or CN-WE $(100 \mu \mathrm{g} / \mathrm{mL})$ for $24 \mathrm{hr}$, and then the cells were harvested, washed, and diluted with the prepared enriched T cells $\left(2 \times 10^{5}\right)$ in ratios of $1: 25,1: 5$, and $1: 1$ (DC: T) in 96-well round-bottom plates (Corning). After an additional $96 \mathrm{hr}$ of coincubation, cell proliferation was assessed by adding $1 \mu \mathrm{Ci}$ of $\left[{ }^{3} \mathrm{H}\right]$ thymidine (GE Healthcare, Buckinghamshire, UK) for overnight incubation; quantification of incorporated $\left[{ }^{3} \mathrm{H}\right]$ thymidine was subsequently performed by liquid scintillation counting on a $\beta$-Counter (Beckman Instruments, Palo Alto, CA, USA).

2.8. OVA-Specific T-Cell Activation. The protocol for OVAspecific T-cell activation was modified from our previous report [23, 24]. Briefly, immature DCs were pulsed with $2 \mu \mathrm{g} / \mathrm{mL} \mathrm{OVA}_{257-264}\left(\mathrm{OVAP}_{1}\right)$ or $\mathrm{OVA}_{323-339}\left(\mathrm{OVAP}_{2}\right)$ (synthesized by Echo Chemical Co., Taiwan) in the presence of LPS or WE-CN $(100 \mu \mathrm{g} / \mathrm{mL})$ for $24 \mathrm{hr}$. CN was then washed out, and $\mathrm{OVAP}_{1}$-specific $\mathrm{CD}^{+} \mathrm{T}$ cells $\left(2 \times 10^{5}\right)$ and $\mathrm{OVAP}_{2}$-specific CD4 ${ }^{+} \mathrm{T}$ cells $\left(2 \times 10^{5}\right)$ were added to the culture at various $\mathrm{DC}: \mathrm{T}$ cell ratios (as indicated) in 96-well round-bottom plates. The OVA-specific cells were positively enriched from the spleens of OT-1 and OT-2 mice by EasySep Mouse CD8a Positive Selection Kit separation and EasySep Mouse CD4 Positive Selection Kit separation, respectively, according to the manufacturer's protocol (Stem Cell Technologies, Grenoble, France). After an additional $72 \mathrm{hr}$ of coincubation, T-cell proliferation was measured by adding $1 \mu \mathrm{Ci}$ of $\left[{ }^{3} \mathrm{H}\right]$ thymidine (GE Healthcare, Buckinghamshire, UK) for overnight incubation; quantification of incorporated $\left[{ }^{3} \mathrm{H}\right]$ thymidine was subsequently performed by liquid scintillation counting on a $\beta$-Counter (Beckman
Instruments, Palo Alto, CA, USA). In addition, the IFN$\gamma$ cytokine levels in the supernatants from DC-OT-I/OTII cultures were determined by a sandwich IFN- $\gamma$ ELISA kit (eBioscience San Diego, CA, USA) according to the manufacturer's protocol.

2.9. Western Blot Analysis. Immature DCs were stimulated with $100 \mu \mathrm{g} / \mathrm{mL}$ WE-CN, and whole cell lysates were prepared at the indicated time points as previously described [23]. The protease inhibitors leupeptin (Sigma-Aldrich, St. Louis, MO, USA) and aprotinin (Sigma-Aldrich, St. Louis, MO, USA) were used at a concentration of at $10 \mu \mathrm{g} / \mathrm{mL}$ in all steps. Protein concentrations were determined using a BCA protein assay kit (Pierce Rockford, IL) prior to western blot or other protein analyses.

For protein detection, protein extracts $(40 \mu \mathrm{g} / \mathrm{mL})$ were boiled separated on 10\% SDS-polyacrylamide gels and electrotransferred to nitrocellulose membranes. The membranes were blocked for $1 \mathrm{hr}$ with $5 \%$ skim milk in TBS $+0.05 \%$ Tween 20. After blocking, the membranes were incubated overnight with the suggested concentrations of either a primary antibody against phospho-p38 (no. 9211), p38 (no. 9212), phospho-p42/44 (no. 9101), total p42/44 (no. 9102), phospho-JNK (no. 4688), and b-Actin (no. 4970) (all purchased from Cell Signaling Technology) or total JNK (SC571) (purchased from Santa Cruz Biotechnology, Danvers, MA, USA). The membranes were washed prior to incubation with HRP-Conjugated Goat Anti-Mouse IgG or HRPConjugated Goat Anti-Rabbit IgG secondary Abs (Jackson ImmunoResearch, West Grove, PA, USA). The proteins were detected by enhanced chemiluminescence (GE Healthcare, UK) and analyzed using the LAS3000 system (Fujifilm, Tokyo, Japan). Densitometric analysis was performed with ImageJ software (National Institute of Health, Bethesda, MD, USA). Active forms of pErk, p38, and pJNK were normalized with corresponding total nonphosphorylated forms.

2.10. Preparation of Nuclear Extracts and NF- $\kappa B$ Activity Assay. Nuclear extracts were prepared using the NE-PER Nuclear and Cytoplasmic Extraction system (Pierce Rockford, IL, USA) according to the manufacturer's instructions. Protein concentrations were determined using a BCA protein assay kit (Pierce, Rockford, IL, USA). For each assay, $5 \mathrm{mg} / \mathrm{mL}$ of nuclear extracted was used in a TransAM NF- $\kappa$ B p 65 ELISA kit (Active Motif, Carlsbad, CA) according to the manufacturer's instructions.

2.11. Therapeutic Efficacy in a Mouse Model of Established MBT-2 Tumors. The MBT-2 tumor model has previously been described [22]. Briefly, MBT-2 cells $\left(1 \times 10^{6}\right)$ in $0.5 \mathrm{~mL}$ of cold PBS were injected subcutaneously (s.c.) into the flanks of female $\mathrm{C} 3 \mathrm{H} / \mathrm{HeN}$ mice. Ten days after injection (when the tumors were palpable), the mice were injected intramuscularly in the left hind thigh muscles with $100 \mu \mathrm{g}$ of the pRC/CMV DNA plasmid (control group), $100 \mu \mathrm{g}$ of a HER-2/neu DNA vaccine (pRC/CMV vector carrying the cDNA encoding the extracellular domain of the human HER$2 / \mathrm{neu}$ ) [25] in $100 \mu \mathrm{L} 0.9 \% \mathrm{NaCl}, 100 \mu \mathrm{g}$ of the pRC/CMV 
DNA plasmid mixed with $100 \mu \mathrm{g}$ WE-CN, or $100 \mu \mathrm{g}$ of the HER-2/neu DNA plasmid mixed with $100 \mu \mathrm{g}$ WE-CN. The mice were injected three times at weekly intervals. The effects of these treatments on the growth of MBT-2 tumors were then monitored twice a week. Tumor volume was calculated using the formula for a rational ellipse: $\left(m_{1} \times m_{2} \times m_{2} \times 0.5236\right)$, where $m_{1}$ represents the longer axis and $m_{2}$ represents the shorter axis. The mice were euthanized when the tumor size reached $>2500 \mathrm{~mm}^{3}$ in mean diameter or the mouse was in poor condition and death was imminent. The significance of differences in survival was tested by the Kaplan-Meier analysis (GraphPad Prism 4.0, La Jolla, CA. USA).

2.12. Quantitative RT-PCR. The quantitative RT-PCR protocol was modified from our previous report $[24,26]$. Three days after the last of DNA vaccination, spleen cells $\left(2 \times 10^{6}\right.$ cells/well $)$ from mice from the different treatment groups were stimulated with recombinant HER-2/neu protein $(10 \mu \mathrm{g} / \mathrm{mL}, \mathrm{R} \& \mathrm{D}$ Systems) in a 24 -well plate for $48 \mathrm{hr}$. After stimulation, $\mathrm{CD} 4^{+} \mathrm{T}$ cells were purified by positive selection (purity $>90 \%$ ) (Stem Cell Technologies, Grenoble, France). Then, total RNA was extracted using the RNAspin Mini Kit (GE Healthcare, Buckinghamshire, UK). cDNA was generated from denatured total RNA using a Transcriptor First Strand cDNA Synthesis Kit (Roche) according to the manufacturer's instructions. The specific primers were used as previously described $[24,26]$ and as described below: IFN- $\gamma$, F: $5^{\prime}$-ACTGGCAAAAGGATGGTGAC- $3^{\prime}$ and R: $5^{\prime}-$ ACCTGTGGGTTGTTGACCTC-3'; IL-4, F: $5^{\prime}$-TCAACCCCCAGCTAGTTGTC-3' and R: 5' -AAATATHCHAAGCACCTTTGG-3'; hypoxanthine guanine phosphoribosyl transferase 1 (HPRT), F: 5' -GTTGGATAAGGCCAGACTTTGTTG-3' and R: $5^{\prime}$-GATTCAACTTGCGCCATCTTAGGC-3'. An Eco Real-Time PCR System (Illumina) and SYBR Green Master Mix (Roche) were used for quantitative real-time PCR. The gene expression was normalized to HPRT expression. These normalized values were then expressed relative to the control group.

2.13. Detection of Antigen-Specific $C D 8^{+} / \mathrm{IFN}-\mathrm{Gamma}^{+} \mathrm{T}$ Lymphocytes in Spleen Cells. The protocol for detection of antigen-specific $\mathrm{CD}^{+} / \mathrm{IFN}^{-}$gamma ${ }^{+} \mathrm{T}$ lymphocytes was modified from our previous report $[23,26]$. After the last DNA vaccination for three days, RBC lysis buffer (eBioscience)-lysed, single-cell spleen suspensions $\left(2 \times 10^{6}\right.$ cells/well) from mice from the different vaccination groups were pulsed for $18 \mathrm{hr}$ with a peptide pool composed of $10 \mu \mathrm{g} / \mathrm{mL}$ each of peptide 362-370 (EFAGKKI) (BioBasic, Canada) and peptide 404-412 (EEITGYLYI) (BioBasic, Canada) of the human HER-2/neu sequence. Brefeldin A $(10 \mu \mathrm{g} / \mathrm{mL})$ (Sigma St. Louis, MO, USA) was added during the last $6 \mathrm{hr}$ of culture. After stimulation, the cells were harvested and surfaced-stained with phycoerythrin- (PE-) conjugated $\mathrm{CD}^{+}$(CLONE 53-6.7) (eBioscience). The cells were subsequently fixed/permeabilized (Cytofix/Cytoperm Plus; BD Biosciences) and stained with FITC-conjugated anti-IFN-gamma (XMG1.2) (eBioscience). The percentage of $\mathrm{CD}^{+}{ }^{+}$IFN-gamma ${ }^{+}$double positive cells among gated CD8+ $\mathrm{T}$ cells was measured using a FACSCalibur flow cytometer
(BD Biosciences), and the data were analyzed using WINMDI software (Scripps, La Jolla, CA, USA). The CD ${ }^{+}$T-cell gating strategy was as follows: the lymphocyte population of the spleen cells was gated on low forward scatter (FSC) versus side scatter (SSC) dot plots, and the FITC-labeled CD8 ${ }^{+}$cells were further gated within the lymphocyte gate. Cells that fulfilled these criteria were acquired $\left(1 \times 10^{4}\right)$.

2.14. Statistical Analysis. All statistical analyses were performed using the GraphPad Prism software package version 4.0. The statistical analyses of cytokine production, surface marker expression, T-cell proliferation, tumor size, and percentage of $\mathrm{CD}^{+} / \mathrm{IFN}$-gamma ${ }^{+} \mathrm{T}$ lymphocytes, western blotting, were performed using one-way ANOVA followed by Tukey's post hoc test. For analysis of the mouse survival rates, the Kaplan-Meier method was used, and statistical significance was determined by log-rank analysis. Values of $P<0.05$ were considered to be statistically significant.

\section{Result}

3.1. WE-CN Can Induce BMDCs Phenotypic Maturation. Mature DCs are characterized by the synthesis and secretion of proinflammatory cytokines, and upregulation of surface costimulatory molecules and major histocompatibility complex molecules with important modulatory functions in inflammatory responses and adaptive immunity [1-3]. Therefore, in the first series of experiments, we investigated the effect of water extract of Clitocybe nuda (WE-CN) on the secretion of the selective proinflammatory cytokines TNFalpha and IL-6, the Th1 cytokine IL-12, and the Th2 cytokine IL-4 in the supernatants of BMDCs by sandwich ELISAs. BMDCs treated with LPS were used as a positive control. As shown in Figure 1, incubation of DCs with WE-CN greatly increased the production of TNF-alpha, IL-6, and IL-12 in a dose-dependent manner, suggesting that WE-CN enhances the maturation and immunostimulatory activity of DCs. The maturation status of BMDCs was also indicated by the enhanced expression of surface molecules on CD11c+ cells. As shown in Figure 2, WE-CN $(100 \mu \mathrm{g} / \mathrm{mL})$ stimulation of BMDCs resulted in significant upregulation of costimulatory molecules (CD80, CD86, and CD40) and major histocompatibility complex molecules (MHC class II and MHC class I) within $24 \mathrm{hr}$ compared to untreated immature BMDCs. Therefore, morphological changes take place as well during the life cycle of DCs: immature DC precursors are often small, round-shaped cells that turn into larger cells with irregular shape and many cytoplasmic protrusions (dendrites) as the cell matures [27]. Thus, we also investigated the effect of WE-CN on the morphological change by phase contrast microscope. As shown in Figure 3, the shapes of LPS- and WE-CN-treated DCs were irregular and have more dendrites compared to the PBS-treated cells after 24-hour treatment. Taken together, these results confirming that WE-CN can induce DC phenotypic maturation.

3.2. WE-CN Increases the Ability of BMDCs to Stimulate OVA-Specific T-Cell Proliferation. A critical function of maturate DCs is to promote antigen-specific T-cell proliferation. 

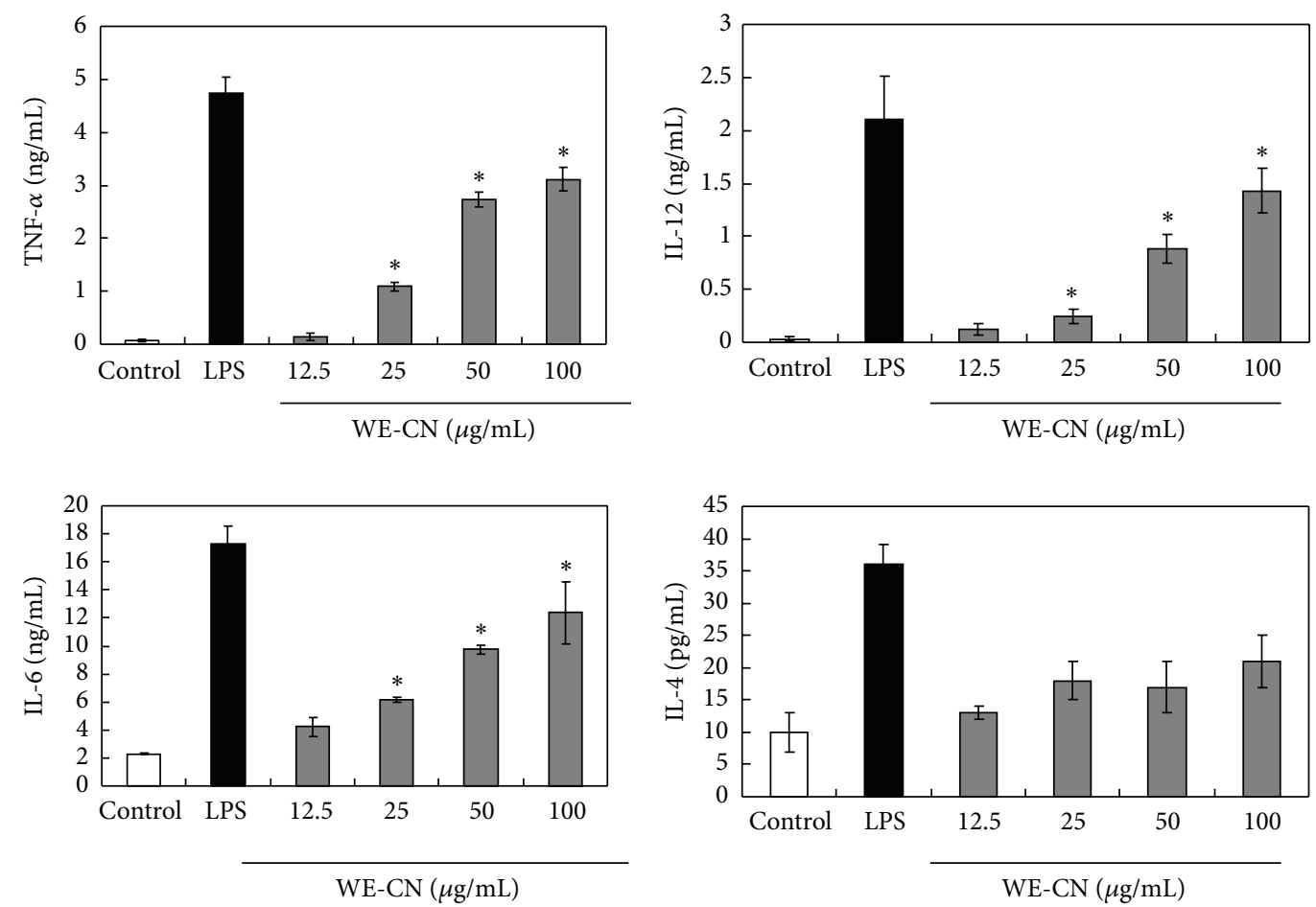

FIGURE 1: Cytokine production is increased in BMDCs stimulated with WE-CN. Immature BMDCs were stimulated with $100 \mathrm{ng} / \mathrm{mL}$ LPS or various concentrations of WE-CN. The control group was treated with PBS alone. Culture supernatants were collected after $24 \mathrm{hr}$ (or $6 \mathrm{hr}$ for TNF-alpha), and the levels of cytokine secretion were analyzed by ELISA. The data are presented as the means \pm SD of samples from three wells. ${ }^{*} \mathrm{P}<0.05$ compared to control. All data are representative of three independent experiments showing similar results.

Therefore, we examined the effect of WE-CN on BMDCmediated allogeneic T-cell proliferation in a mixed lymphocyte reaction (MLR). As shown in Figure 4, at DCto-T cells ratios of $1: 1$ and $1: 5$, WE-CN-treated DCs significantly induced more proliferation of naïve allogeneic $T$ cells than those PBS-treated DCs did. To further compare the stimulatory properties of DC cultured with WE$\mathrm{CN}$, we next examined the effect of WE-CN on BMDCmediated activation of OVA antigen-specific T-cell responses. CN-treated, $\mathrm{OVA}_{257-264}\left(\mathrm{OVAP}_{1}\right)$, or $\mathrm{OVA}_{323-339}\left(\mathrm{OVAP}_{2}\right)$ peptide-loaded BMDCs were cocultured with their allogeneic OVA-specific $\mathrm{CD}^{+}$OT-II or $\mathrm{CD}^{+}$OT-I T cells, and T-cell proliferation was measured by $\left[{ }^{3} \mathrm{H}\right]$ thymidine incorporation. Our results showed that WE-CN-activated BMDCs effectively induced enhanced OVA-specific $\mathrm{CD} 4^{+}$ (OT-II) and $\mathrm{CD}^{+}$(OT-I) T proliferative responses in vitro (Figure 5). In addition, because IFN- $\gamma$ is produced by activated T cells, the IFN- $\gamma$ levels in the culture supernatants were also measured using ELISA. As shown in Figure 5, WE-CN treatment also increased the amount of INF- $\gamma$ produced by the activated $\mathrm{CD} 4^{+}$and $\mathrm{CD} 8^{+} \mathrm{T}$ cells. These results revealed that WE-CN enhances the ability of DCs to induce Agspecific $\mathrm{T}$-cell immune responses.

\subsection{WE-CN Increases MAPK and NF- $\kappa B$ Pathways Activation} in BMDCs. As previously shown, the activation of MAPKs and NF- $\kappa \mathrm{B}$ plays a crucial role in DC maturation and response to inflammatory stimuli $[28,29]$. To gain additional insight into the molecular mechanism underlying the effects of WE-CN, we sought to study the effect of WE-CN treatment on the MAPK and NF- $\kappa$ B pathways in BMDCs. BMDCs were stimulated with WE-CN, and the levels of MAPK phosphorylation were assessed by western blotting. Our results showed that WE-CN can upregulate the phosphorylation of the MAPKs ERK, p38, and JNK between 60 and $120 \mathrm{~min}$ after treatment, whereas the levels of the nonphosphorylated proteins were not affected (Figure 6(a)). To further determine whether WE-CN increases the activation of NF- $\kappa$ B, nuclear extracts were collected and analyzed for NF- $\kappa \mathrm{B}$ binding activity using an ELISA-based assay. As shown in Figure 6(b), CN treatment resulted in an increase in the nuclear translocation of p 65 and upregulated NF- $\kappa$ B binding activity at $3 \mathrm{hr}$ after stimulation. Therefore, these results suggest that $\mathrm{CN}$ induces $\mathrm{DC}$ activation, possibly through activation of the MAPK and NF- $\kappa$ B pathways, which partially explains the activating effect of WE-CN on DC maturation.

3.4. BMDCs from TLR-4/2-Deficient Mice Do Not Respond to WE-CN Stimulation. The recognition of certain mushroom compounds, such as water soluble polysaccharide proteoglycans and proteins, by TLR-2 and TLR- 4 has been demonstrated in DCs and is required for optimal DC activation [24, 25, 30, 31]. Therefore, we further assessed whether TLR-2 and/or TLR-4 receptors were involved in WE$\mathrm{CN}$-induced DC activation. The TLR-4-deficient $(\mathrm{C} 3 \mathrm{H} / \mathrm{HeJ})$ and TLR- $2^{-1-}$ (C57BL/6 background) mouse strains are 

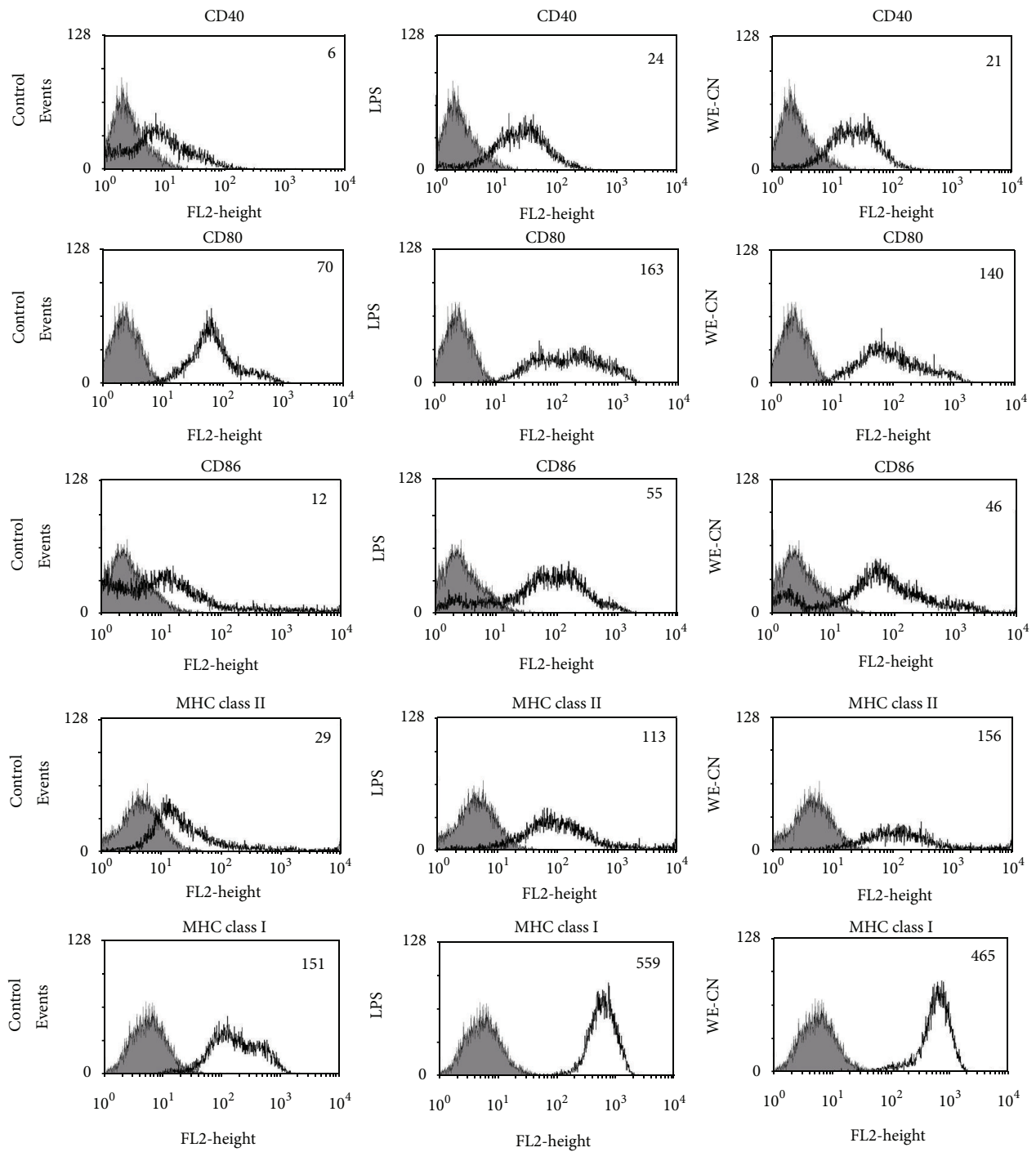

(a)
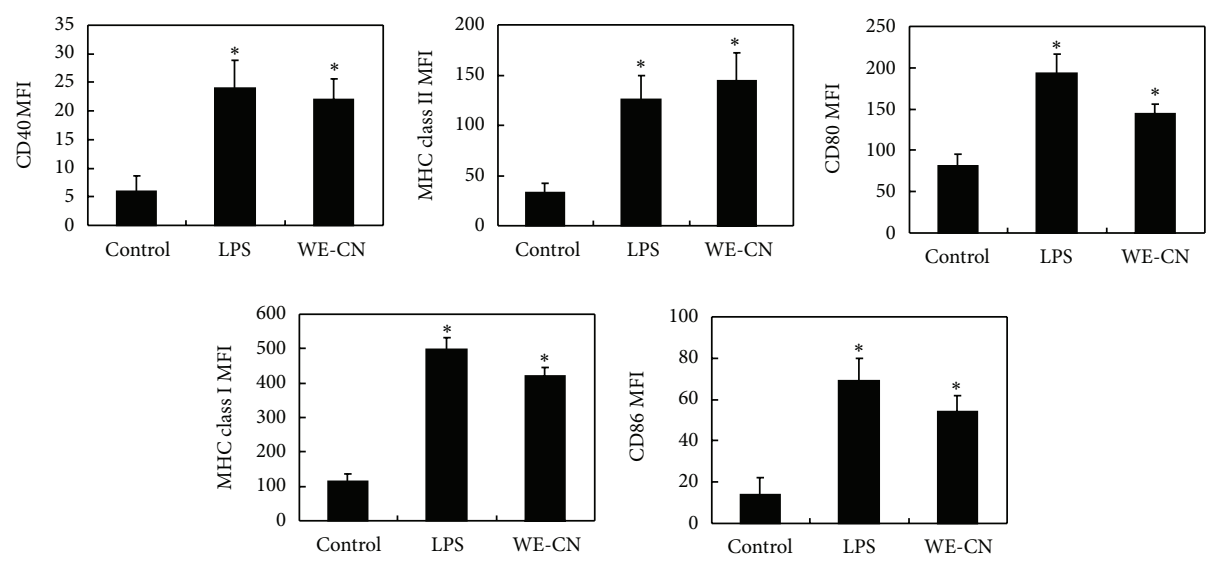

(b)

FIGURE 2: WE-CN upregulates the expression of immunomodulatory cell surface markers on BMDCs. Immature BMDCs were stimulated with $100 \mathrm{ng} / \mathrm{mL}$ LPS or $100 \mu \mathrm{g} / \mathrm{mL}$ WE-CN for $24 \mathrm{hr}$. The control group was treated with PBS alone. After incubation, the expression of the surface markers CD40, CD80, CD86, MHC class I, and MHC class II was analyzed by flow cytometry with fluorescently labeled Abs. All data were gated on CD11c ${ }^{+}$cells. The gray-filled area represents staining with an isotype-matched control Ab. (a) The histogram shows data from one representative experiment of each group. (b) The bar graphs represent the mean \pm SD from three independent experiments. 

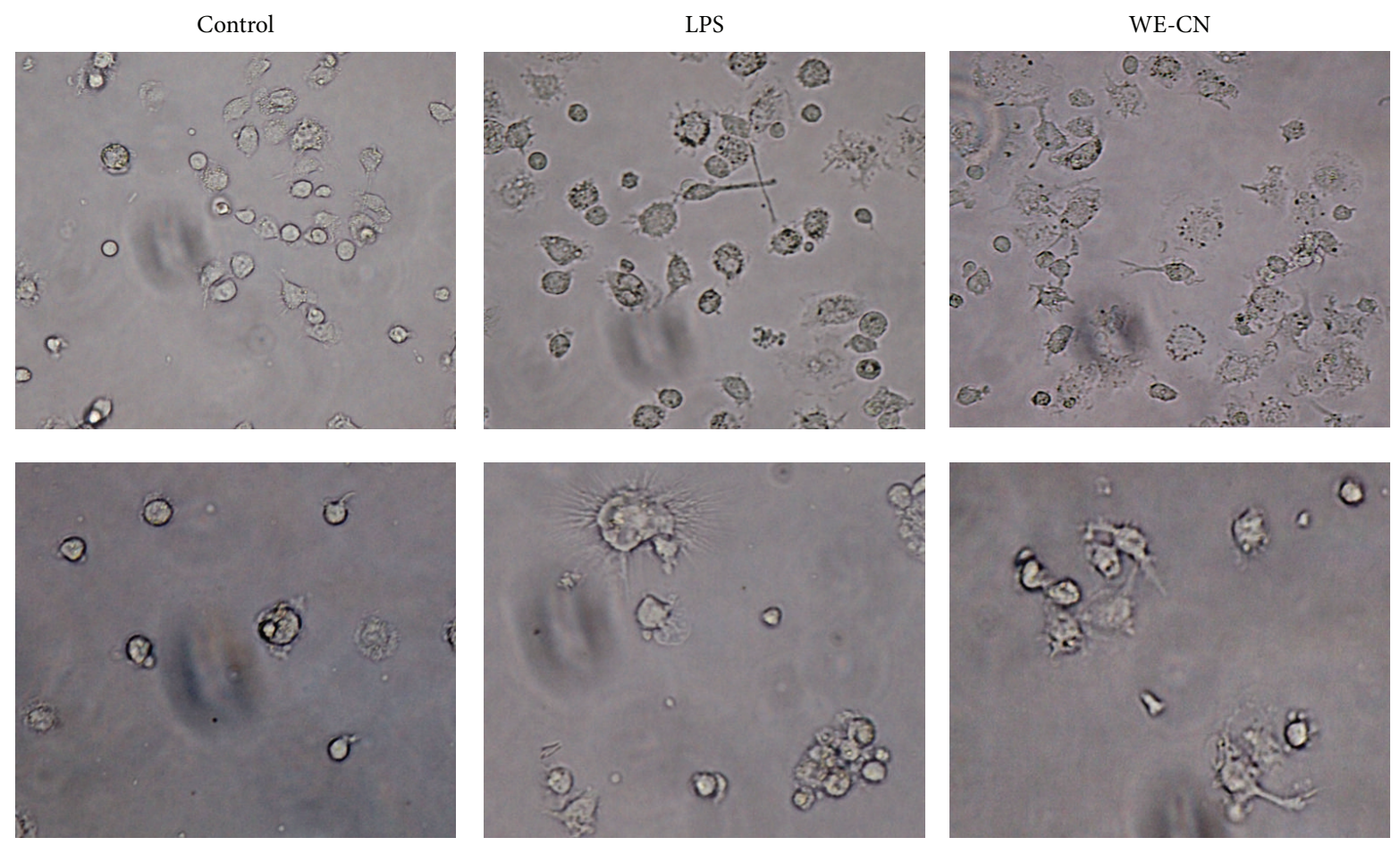

FIgURE 3: Morphology of the BMDCs treatment with PBS, LPS, or WE-CN under a light microscopy $(\times 200)$.

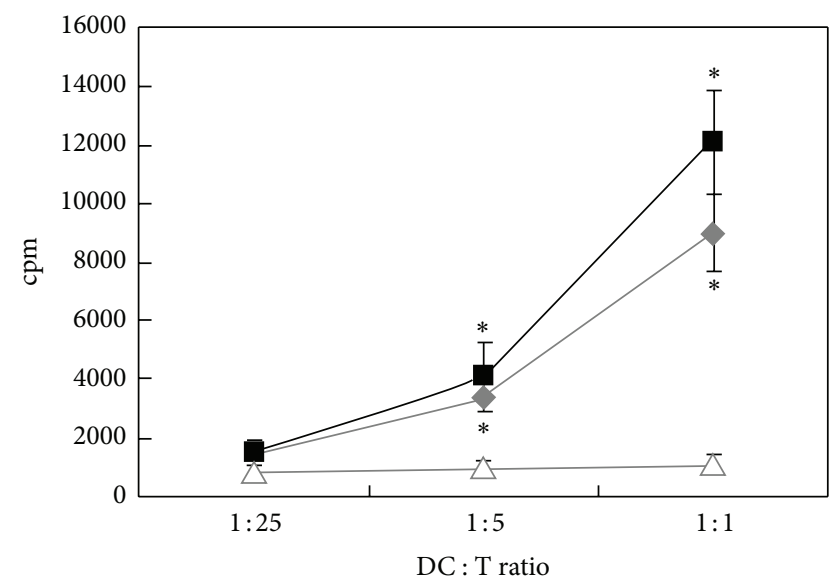

FIGURE 4: WE-CN induces the capability of stimulating allogeneic T-cell response in MLR of BMDCs. T cells were prepared from the spleens of naïve C57BL/6 mice. Purified $\mathrm{T}$ cells were then cocultured with PBS-, LPS- $(100 \mathrm{ng} / \mathrm{mL})$, or WE-CN- $(100 \mu \mathrm{g} / \mathrm{mL})$ treated BMDCs at the indicated ratio of DC: T cells for $96 \mathrm{hr}$. Cell proliferation was measured by $\left[{ }^{3} \mathrm{H}\right]$-thymidine incorporation for $18 \mathrm{hr}$. The data shown represent the mean $\pm \mathrm{SD}$ of samples from three wells. ${ }^{*} P<0.05$ compared to control. All data are representative of three independent experiments showing similar results.

nonresponsive to LPS and lipoteichoic acid (LTA) due to a point mutation or knockout of their TLR-4 or TLR-2 receptor genes, respectively $[25,30,31]$. We used these mice to further characterize the function of TLR-4 or TLR-2 in WECN-mediated DC stimulation. Bone marrow-derived DCs from $\mathrm{C} 3 \mathrm{H} / \mathrm{HeJ}$ or TLR-2 ${ }^{-/-}$mice and wild-type $\mathrm{C} 3 / \mathrm{HeN}$ or C57BL/6 mice were prepared and phenotypically analyzed. As shown in Figure 7(a), LPS and LTA did not induce significant IL-12 production in TLR-4-deficient or TLR-2 ${ }^{-/-}$ BMDCs, respectively. In addition, WE-CN stimulated IL12 production in a dose-dependent manner in wild-type DCs as expected; however, IL-12 production was dramatically reduced in BMDCs from both TLR-4-deficient and TLR-2 $\mathrm{KO}$ mice. We next examined whether the nonresponsiveness of DCs from TLR-4 mutant or TLR-2 KO mice to WE-CNstimulation is functionally related to their NF- $\kappa \mathrm{B}$ activity. As shown in Figure $7(\mathrm{~b})$, the NF- $\kappa \mathrm{B}$ activity of the DCs from TLR-4 and TLR-2 mutant mice was significantly lower upon WE-CN treatment compared with wild-type DCs. Taken together, these results show that WE-CN can induce BMDC maturation through interaction with TLR-4 and/or TLR-2 molecules.

3.5. WE-CN Enhanced the Antitumor Effect of a HER-2/neu DNA Vaccine. We have previously demonstrated that an intramuscular HER-2/neu DNA vaccine has a therapeutic effect on established $185^{\text {neu }}$-expressing MBT-2 tumors in $\mathrm{C} 3 \mathrm{H} / \mathrm{HeN}$ mice $[22,32,33]$. Using this model, we further examined whether WE-CN can increase the efficacy of a HER-2/neu DNA vaccine. As shown in Figure 8(a), immunization with either the control vector alone or control vector plus $100 \mu \mathrm{g} / \mathrm{mL}$ WE-CN did not exert therapeutic effects on MBT-2 tumor growth, and all mice in these two groups had to be sacrificed due to the size of their tumors or their overall health; these mice were expected to have become moribund by day 35 at the latest. In contrast, when the mice 

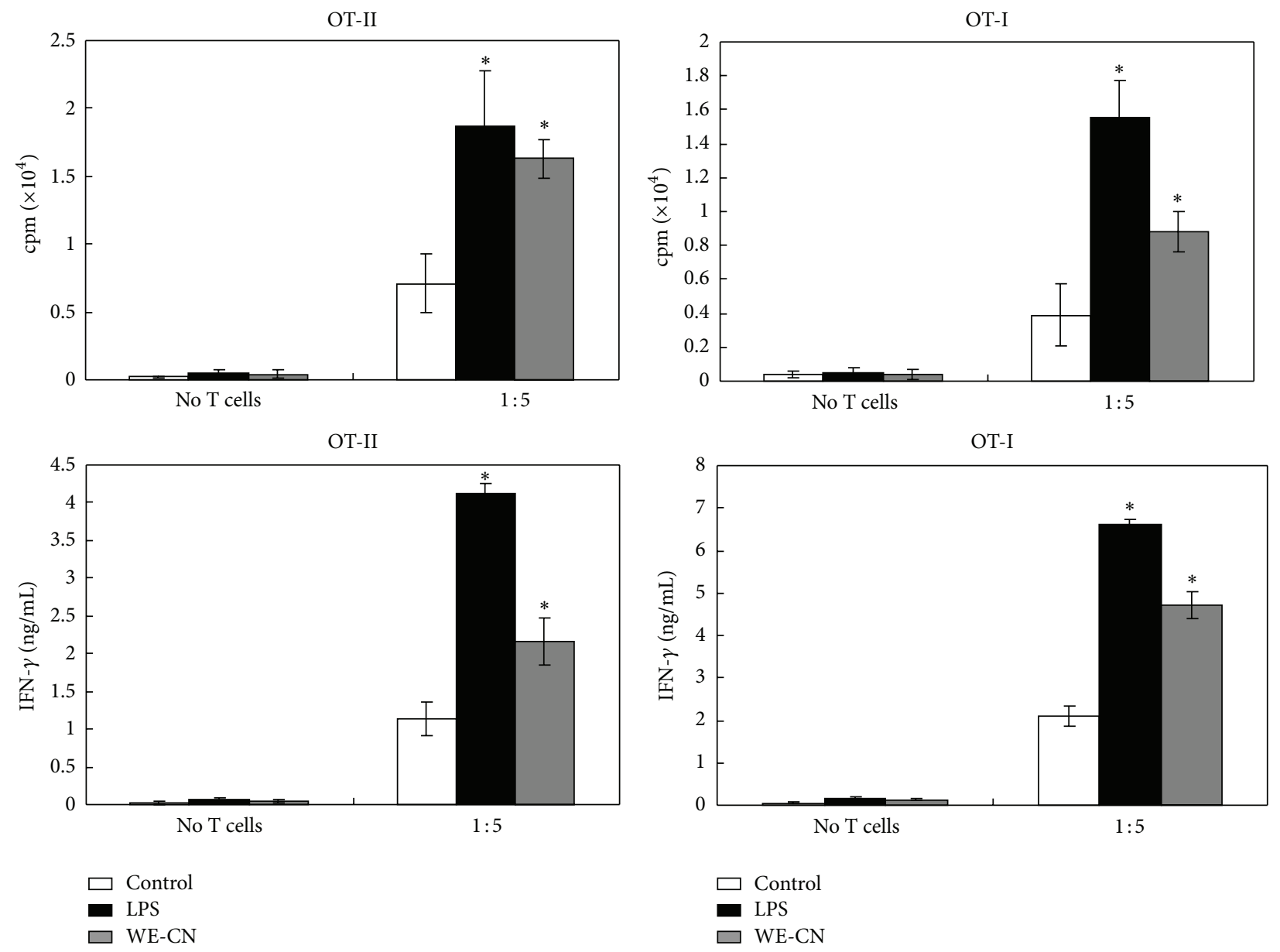

Figure 5: WE-CN-treated BMDCs increase T-cell activation in response to the specific antigen OVA. (a) CD8 ${ }^{+} \mathrm{T}_{\text {cells }}$ and $\mathrm{CD} 4^{+} \mathrm{T}$ cells were prepared from the spleens of OT-I and OT-II mice, respectively. Purified T cells were cocultured with PBS-, LPS- (100 ng/mL), or WE-CN$(100 \mu \mathrm{g} / \mathrm{mL})$ treated DCs pulsed with an OVA peptide at the indicated ratio of DC:T cells for 96 hr. Cell proliferation was quantified by $\left[{ }^{3} \mathrm{H}\right]$-thymidine incorporation for $18 \mathrm{hr}$. (b) Supernatants were collected from cultures after 4 days, and IFN- $\gamma$ production was measured by ELISA. The data shown represent the mean \pm SD of samples from three wells. ${ }^{*} P<0.05$ compared to control. All data are representative of three independent experiments showing similar results.

were vaccinated with the HER-2/neu DNA alone or HER$2 /$ neu DNA plus WE-CN $(100 \mu \mathrm{g})$, the growth of the tumors was significantly reduced compared to tumors at earlier time points. However, injection with HER-2/neu DNA plus WE$\mathrm{CN}$ markedly prolonged survival compared to the HER2/neu DNA alone (Figure 8(b)). These results clearly indicate the additional benefit of $\mathrm{CN}$ on the therapeutic efficacy of the HER-2/neu DNA vaccine.

3.6. WE-CN Promoted the Th1 Immune Responses Induced by HER-2/neu DNA Vaccination. Our previous study demonstrated that Thl-based immune responses, specifically the generation of cytotoxic $\mathrm{CD}^{+} \mathrm{T}$ cells, represent the primary immunological mechanism for the suppression of the implanted MBT-2 tumors in mice [22-24, 26, 32, 33]. In addition, we have shown that WE-CN-stimulated DCs preferentially release the Th1-dominant cytokine IL-12 (Figure 1) and facilitate Th1 CD4 ${ }^{+}$differentiation (Figure 5). Therefore, we hypothesized that WE-CN promotes Th1 immune responses that consequently enhance the antitumor immunity resulting from HER-2/neu DNA vaccination. To test this possibility, spleen cells collected from mice in the different vaccination groups were stimulated with recombinant HER-2/neu protein, and the expression of IFN- $\gamma$ (Th1) and IL-4 (Th2) within purified $\mathrm{CD} 4^{+} \mathrm{T}$ cells was determined by a qPCR assay. As shown in Figure 9(a), mice immunized with the HER2/neu DNA vaccine-CN combination showed significantly higher levels of IFN- $\gamma$ than those immunized with the HER2/neu DNA vaccine alone; no significant differences were observed in IL-4 production. To further examine the HER2/neu-specific $\mathrm{CD}^{+}$responses in vaccinated mice, we used flow cytometry to analyze the intracellular expression of IFN- $\gamma$ in $\mathrm{CD}^{+} \mathrm{T}$ cells. As shown in Figure 9(b), spleen cells collected from mice immunized with the HER-2/neu DNA vaccine/WE-CN combination generated more HER2/neu-specific $\mathrm{CD}^{+}$IFN-gamma T cells than those of the mice immunized with the HER-2/neu DNA vaccine alone. These results suggest that coadministration of the HER-2/neu vaccine with WE-CN may elicit stronger HER-2/neu-specific Th1 responses induced by HER-2/neu DNA vaccination, 

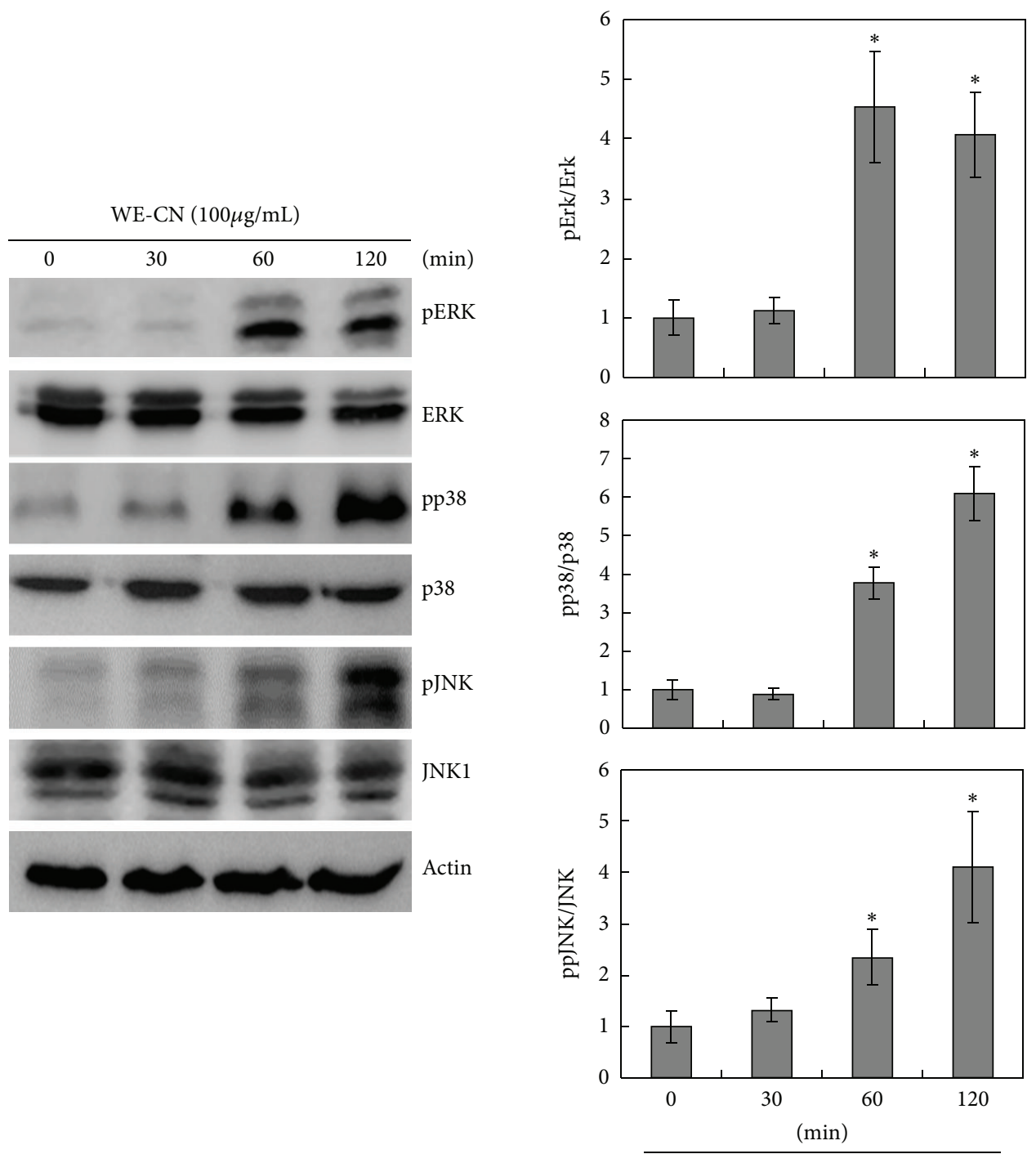

WE-CN $(100 \mu \mathrm{g} / \mathrm{mL})$

(a)

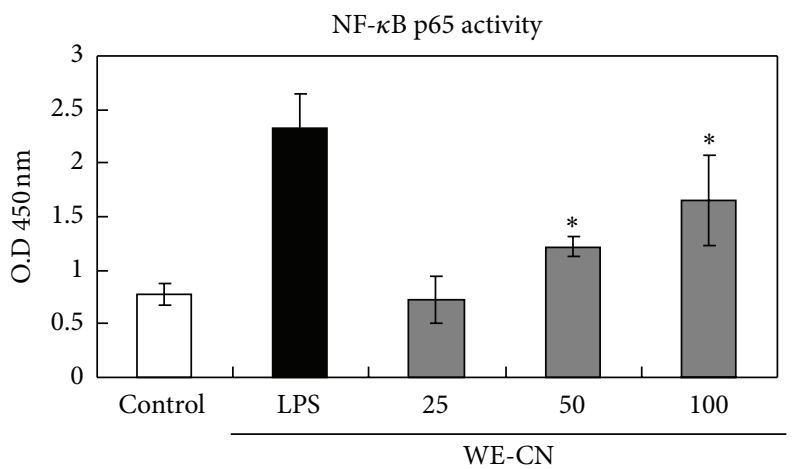

(b)

FIGURE 6: WE-CN induces MAPK phosphorylation and NF- $\kappa$ B binding activity in BMDCs. Immature BMDCs were treated with WE-CN $(100 \mu \mathrm{g} / \mathrm{mL})$, and whole cell lysates or the cytosolic fraction of lysates was collected at the indicated time points. (a) MAPK phosphorylation levels were analyzed by western blot analysis with anti-ERK, anti-JNK, and anti-p38 MAPK antibodies (against both phosphorylated and nonphosphorylated forms of the proteins). pErk, pp38, and pJNK 2 levels were normalized with total Erk, p38, and JNK levels and then compared with the control group arranged as one unit. The data represent the mean \pm SD of samples from three independent experiments. (b) The NF- $\kappa$ B assay was described in Section 2. The NF- $\kappa$ B binding activity is shown as relative OD450 levels. The data represent the mean \pm SD of samples from three wells. ${ }^{*} P<0.05$ compared to control. The data are representative of three independent experiments showing similar results. 


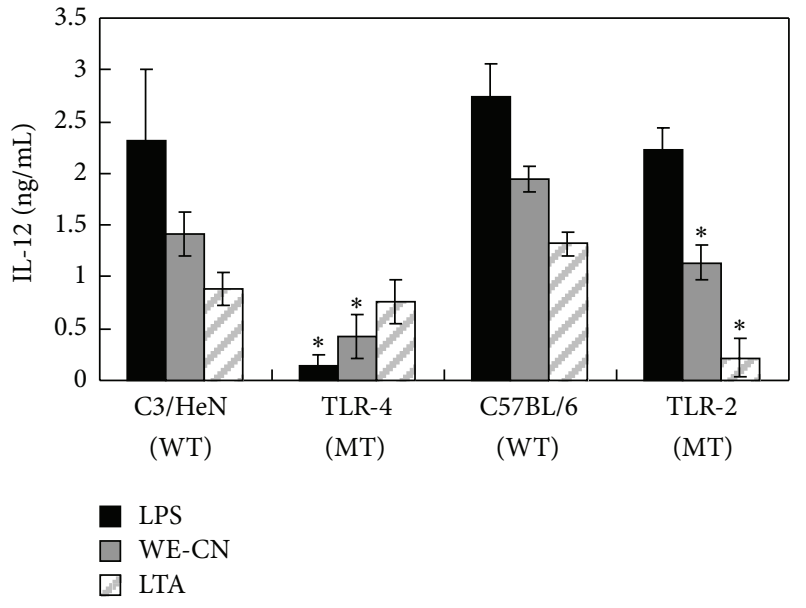

(a)

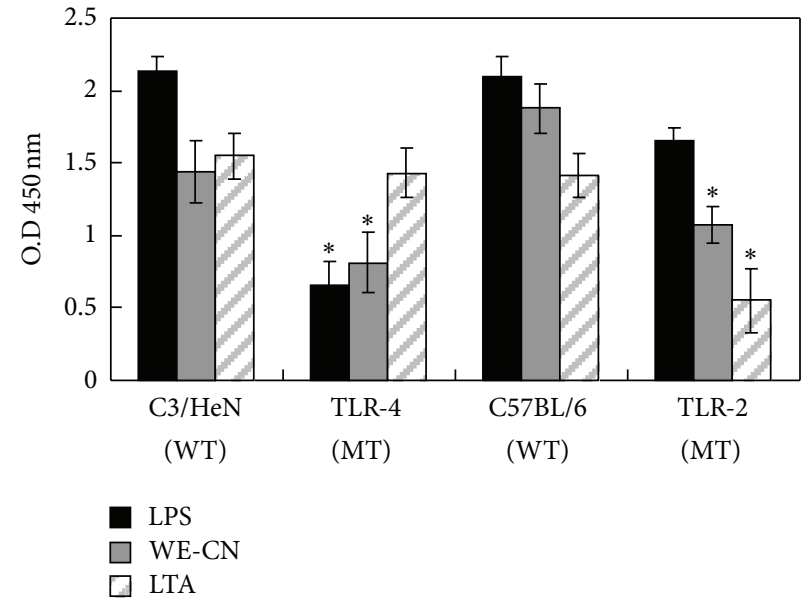

(b)

FIGURE 7: WE-CN induces IL-12 expression and NF- $\kappa \mathrm{B}$ activity through a TLR-4- and/or TLR-2-dependent signaling pathway. BMDCs were harvested from $\mathrm{C} 3 \mathrm{H} / \mathrm{HeN}, \mathrm{C} 3 \mathrm{H} / \mathrm{HeJ}$ (TLR-4-deficient), C57BL/6, or TLR-2 KO mice and stimulated with WE-CN (100 $\mu \mathrm{g} / \mathrm{mL}), \mathrm{LPS}$ $(100 \mathrm{ng} / \mathrm{mL})$ or LTA $(1 \mu \mathrm{g} / \mathrm{mL})$. (a) IL-12 cytokine production and (b) NF- $\kappa$ B binding activity were measured $24 \mathrm{hr}$ later (or $3 \mathrm{hr}$ later for the NF- $\kappa$ B binding assay). The data shown represent the mean \pm SD of samples from three wells. ${ }^{*} P<0.05$ for the comparison between stimulated BMDCs from the mutant mice and their relevant wild-type control group. All data are representative of three independent experiments showing similar results.

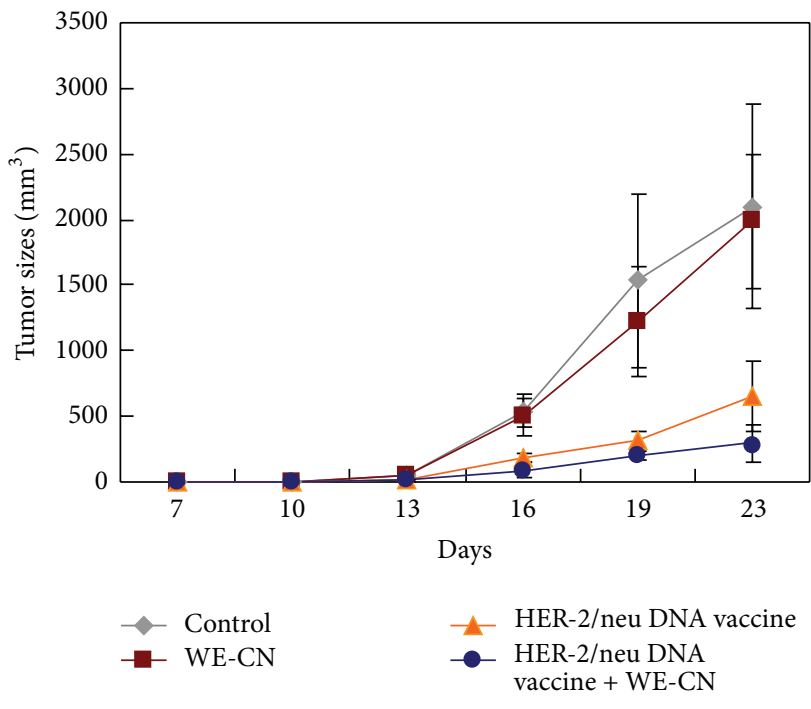

(a)

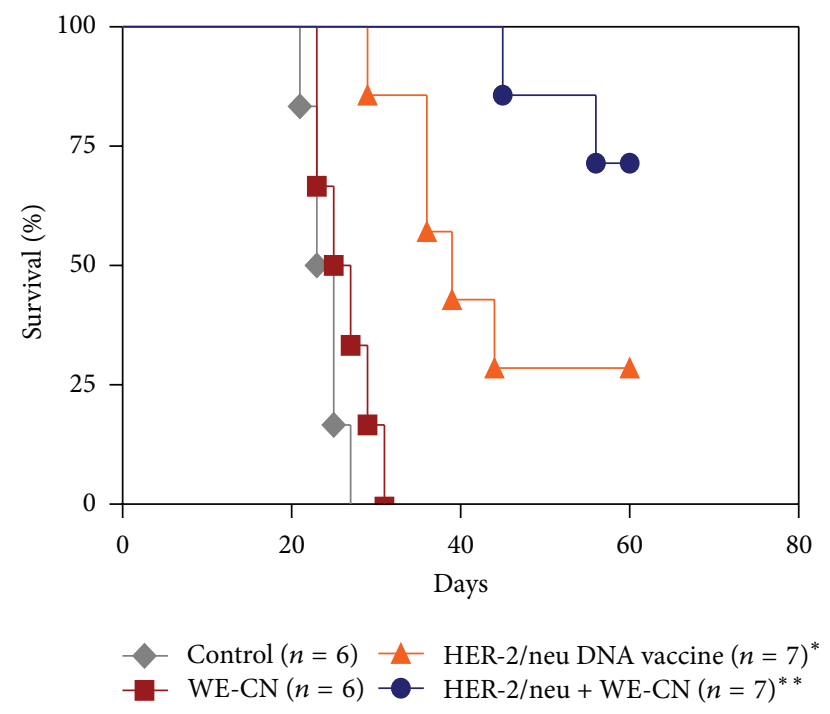

(b)

FIGURE 8: WE-CN enhances the therapeutic effects of a HER-2/neu DNA vaccine against MBT-2 tumors in C3H/HeN mice. Ten days after s.c. MBT-2 inoculation, the tumor-bearing mice were vaccinated with the indicated formulas. (a) The tumor volumes were measured at the indicated times. The mean values \pm SD from six to seven mice per group are shown. (b) The Kaplan-Meier survival curve for the different groups of mice is shown. The symbol ${ }^{*}$ indicates a statistically significant difference compared with control group $(P<0.05)$. The symbol ${ }^{* *}$ indicates comparison with the HER-2/neu DNA vaccine alone group $(P<0.05)$. The data are representative of three independent experiments with similar results.

which could enhance the antitumor efficacy of the HER2/neu DNA vaccine.

\section{Discussion}

Dendritic cells (DCs) are a crucial cell type that acts at the interface of innate and adaptive immune responses and has the unique ability to activate naive T cells [1-3]. Potent modulation of the activation and function of this essential cell type might have potential efficacy against tumor or virus infection or represent a candidate adjuvant approach for application in immunotherapy and vaccination [4]. In this study, we examined the activity of water extract of C. nuda (WE-CN) on the immune function of DCs. Our 


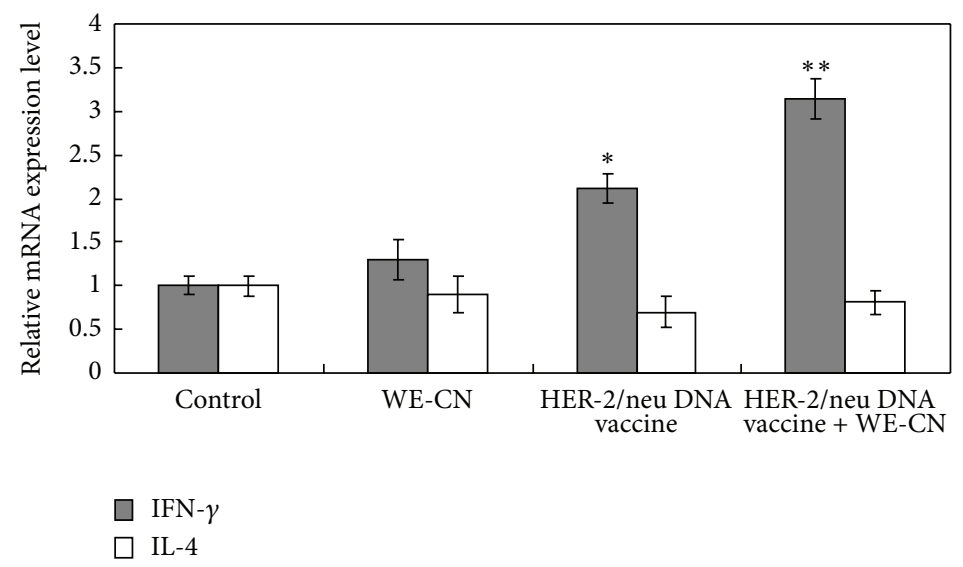

(a)

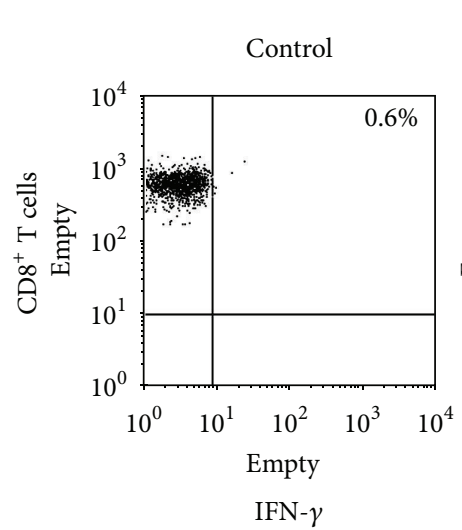

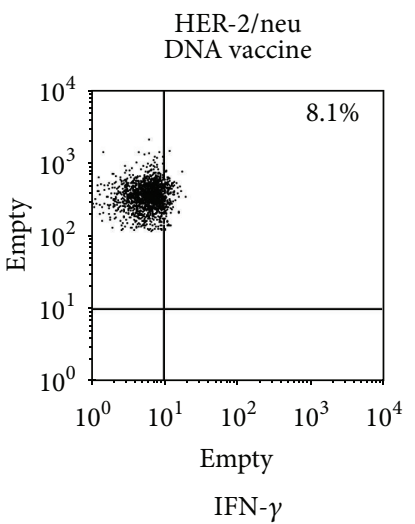

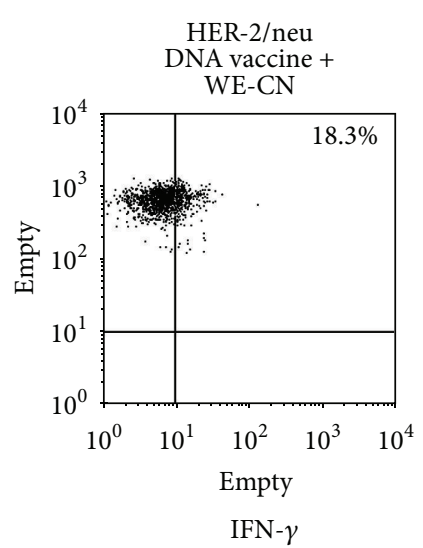

(b)

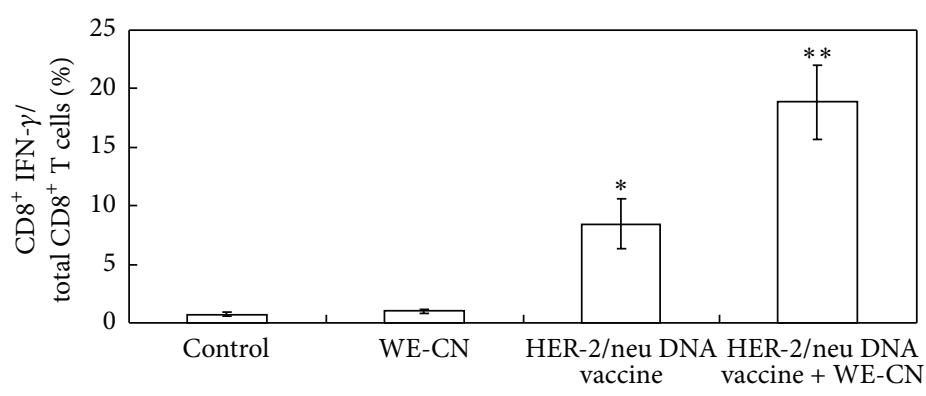

(c)

FIgURE 9: WE-CN promotes $\mathrm{CD} 4^{+}$Th1 differentiation and increased HER-2/neu-specific functional $\mathrm{CD} 8^{+} \mathrm{T}$ cells in spleens from vaccinated mice. (a) $\mathrm{CD}^{+} \mathrm{T}$ cells were purified from the different groups and stimulated with recombinant HER-2/neu protein $(10 \mu \mathrm{g} / \mathrm{mL})$. After 3 days, the expression levels of IFN- $\gamma$ or IL- 4 mRNA were determined by quantitative real-time RT-PCR. The data were normalized to HPRT expression in each sample, and error bars indicate the mean \pm SD of six mice per group assessed from three independent experiments. (b) The spleen cells from the different vaccinated groups were stimulated with a peptide pool composed of $10 \mu \mathrm{g} / \mathrm{mL}$ each of peptide $362-370$ (EFAGKKI) (BioBasic, Canada) and peptide 404-412 (EEITGYLYI) of the HER-2/neu sequence. After stimulation for $18 \mathrm{hr}$, the percentage of IFN-gamma-producing CD8+ T cells was determined by flow cytometry. The dot plot shows data from one representative mouse from each group. The bar graph represents the mean \pm SD of five mice from two independent experiments. The symbol ${ }^{*}$ indicates a statistically significant difference compared to control vector-treated mice $(P<0.05)$. The symbol ${ }^{* *}$ indicates a statistically significant difference compared to the HER-2/neu DNA vaccine alone group $(P<0.05)$.

results show that WE-CN induces DC maturation, based on the levels of costimulatory molecules and cytokines, and promotes the activation of allogeneic $\mathrm{T}$ cells as the primary DC function. This study is the first to report that
C. nuda has immunostimulatory activity on immune systems.

DCs are believed to regulate T-cell-mediated immunity. In addition, the type of cytokines synthesized and released by 
DCs upon activation is believed to play an important role in determining the fate choice of naïve $\mathrm{CD} 4^{+} \mathrm{T}$ cells, which can be subdivided into Th1, Th2, and Th17 cells and Treg cells [34]. Specifically, IL-12 is a pivotal cytokine for Th1 differentiation, whereas IL-4 inhibits Th1 but promotes Th2-type responses [35]. In the present study, we observed that WE-CN can significantly increase IL-12 production but does not affect IL- 4 production in BMDCs (Figure 1). In addition, we also showed that coculture of WE-CN-stimulated OVA peptidepulsed BMDCs and OVA-specific T cells can significantly increase IFN- $\gamma$ production (Figure 5), which is a major product of Th1 cells [36]. Thus, these results indicate that WE-CN-stimulated DCs preferentially promote Thl immune responses. Therefore, $C$. nuda may be effective in antitumor or antiviral effects or for the treatment of allergic diseases (which are Th2-dominant immune responses) by resultant augmentation of Th1 cells.

Recently, IL-17-producing (Th17) cells have been identified as a novel class of helper $\mathrm{CD}^{+} \mathrm{T}$ cells [37]. IL-17 plays an important role in host defense against bacterial or fungal infections [38-41]. In addition, Th17 is also related to the pathogenesis of many chronic inflammatory diseases and autoimmune diseases $[42,43]$. It has been shown that transforming growth factor- $\beta$ (TGF- $\beta$ ), IL-6, IL-21, and IL23 are involved in Th17 differentiation $[44,45]$. We found that WE-CN significantly enhances the IL- 6 production by DCs, suggesting that Th17 may be induced by WE-CN. However, we focused on the adjuvant effect of WE-CN and did not examine the induction of Th17 in this study.

Our present study showed that active MAPKs (ERK, p38, and JNK) and NF- $\kappa \mathrm{B}$ signaling pathways result in DC maturation (Figure 6). Because NF- $\kappa$ B binding sites are found in the promoter regions of various proinflammatory cytokines, including TNF-alpha, IL-6, and IL-12 [46-48], and of costimulatory molecules, such as CD40 and CD86 $[49,50]$, the NF- $\kappa \mathrm{B}$ pathway may be involved in WE-CNinduced DC activation. However, the reported role of the MAPK signaling pathway in DC maturation is controversial. p38 mitogen-activated protein kinase is well known to play an important role in DC maturation [29]. Lin et al. have shown that the ERK signaling pathway is required for DC maturation and cytokine production by polysaccharide purified from Ganoderma lucidum [51]. In contrast, the ERK pathway has also been shown to lead to differentiation of tolerogenic DCs [52]. Moreover, a previous study has shown that ERK and JNK signaling pathways activation in DCs favors a Th2 response, whereas p38 pathway activation favors a Th1 response [53-55]. One possible explanation is that the duration and intensity of MAPK signaling activation during DC maturation may differ in response to different stimuli, and different activation patterns of multiple signaling pathways may result in varied consequences. Further studies using pharmacological inhibitors of the MAPK pathway or overexpression of small interference RNA and dominantnegative gene strategies are required to clarify the importance of the intensity and duration of p38, ERK, and JNK phosphorylation in WE-CN-induced DC activation.

Recent data have suggested that stimulation through tolllike receptors (TLRs) is required for the innate immune response and optimal DC activation [56]. In the present study, using BMDCs from TLR-4 and TLR-2 mutant mice, we found that WE-CN induced DC maturation at least in part through interaction with TLR-4 and TLR-2 (Figure 7). The specific components of WE-CN that contribute to the observed effect on DCs remain unclear. Previous studies have shown that water-soluble polysaccharides, specifically $\beta-1,3$ glucans with $\beta-1,6$ linked side chains, proteoglycans, and proteins (such as fungal immunomodulatory protein (FIP) isolated from a various types of edible mushrooms), display similar effects on DCs by acting on toll-like receptor- 2 and/or $-4[24,25,30,31,57,58]$. Therefore, we suggest that the effects of WE-CN on DC activation may be attributed to the polysaccharide, proteoglycan, and/or protein content of WE$\mathrm{CN}$; however, all of these possibilities require further study.

We identified $\mathrm{CN}$ water extracts as novel ligands for TLR-4 and TLR-2. Because TLR-4 is one of the major components of the receptor for LPS and concentrations as low as $50 \mathrm{pg} / \mathrm{mL}$ are sufficient to promote DC activation [59], the possibility of contamination with the endotoxin LPS in the $\mathrm{CN}$ preparations used in this study required examination. LAL assays showed endotoxin content of $<0.1 \mathrm{ng} / \mathrm{mL}$ in our $1 \mathrm{mg} / \mathrm{mL} \mathrm{CN}$ stock solutions, resulting in a maximum possible contamination throughout the assays of $0.01 \mathrm{ng} / \mathrm{mL}$ in the $100 \mu \mathrm{g} / \mathrm{mL}$ concentration of WE-CN. Titration experiments with purified LPS (Escherichia coli, serotype O26:B6) were performed and indicated that DCs under the culture conditions used in our experiments failed to mature in response to LPS concentrations of $<0.1 \mathrm{ng} / \mathrm{mL}$. (see supplemental Figures 1(a) and 1(b) in supplementary material available online at http://dx.doi.org/10.1155/2013/761454). Furthermore, in blocking experiments for LPS, BMDCs were incubated with $5 \mu \mathrm{g} / \mathrm{mL}$ of the LPS inhibitor polymyxin B prior to WE-CN stimulation. Polymyxin B did not significantly affect the CN-induced IL-12 production and upregulation of CD80 but almost completely inhibited the LPS effect in the same experiment (supplemental Figure 2). Therefore, these data suggest that CN water extract causes DC maturation in part by binding to TLR- 4 and/or TLR- 2 .

Our results showed that WE-CN can activate DCs in part by interaction with TLR-4/TLR-2 receptors (Figure 7). However, in addition to DCs, various other types of immune cells (including macrophages and B lymphocytes) can also express TLR and respond to TLR ligands [60]. Therefore, further examination of the direct effects of WE-CN on the functions of other immune cells, such as B cells and macrophages, is warranted.

DNA vaccines have been reported to generate high antigen-specific immunity in animal models for treating various diseases, including established tumors; however, poor immunogenicity in large animals and humans is the major obstacle for the practical use of these vaccines [61-63]. Therefore, the development of novel approaches to increase the immunogenicity of DNA vaccines and circumvent this limitation is urgently needed. To this end, combining DNA vaccination with strong adjuvants is one strategy to enhance the immunogenicity of DNA vaccines [64]. Our present study showed for the first time that the addition of WE-CN $(100 \mu \mathrm{g})$ significantly enhanced the antitumor effect of a HER-2/neu 
DNA vaccine on tumor growth, resulting in a higher survival rate compared to the HER-2 DNA vaccine alone group (Figure 8). Further studies revealed the mechanisms by which WE-CN induces antigen-specific Th1 responses, including increased functional $\mathrm{CD} 8^{+} \mathrm{T}$ cell populations in spleen cells and induction of elevated IFN-gamma mRNA expression levels compared to the HER-2 DNA vaccine alone group (Figure 9). Therefore, these data (corresponding to the results in Figures 1 and 5) suggest that WE-CN-stimulated DCs preferentially promote Thl immune responses. Moreover, although we used HER-2/neu as a model antigen to demonstrate the adjuvant effects of WE-CN in this study, we propose that our results are encouraging for the application of $C$. nuda extract to enhance the potency of DNA vaccines or other immunotherapies for the control of other cancers and infectious diseases.

In summary, for the first time, we present evidence demonstrating that water extract of C. nuda can augment DC maturation in an in vitro culture system and contains adjuvant activity for DNA vaccines and therapeutic antitumor potential in a tumor-bearing mouse model. We suggest that these data may highlight the nutritional and medical value of C. nuda and can be used as the basis for further research. However, additional issues still warrant future investigation. For example, in this study, because we used a crude water extract of whole C. nuda concentrate, the identity of the specific components of the C. nuda extract that contribute to the observed effect on DCs is unclear. Therefore, further studies are required to identify the specific active component(s) that is responsible for the observed effect of WE-CN. In addition, we employed an in vitro culture model in this study to determine the effect of WE-CM on BMDC maturation, but we are aware that an in vivo (oral administration and feeding) design may be more applicable for defining the effects of dietary mushrooms as a nutritional intervention. Thus, further examination of whether the in vitro effects can be recapitulated in vivo (through oral administration and feeding) will be very important.

\section{Conflict of Interests}

The authors declare that they have no conflict of interests.

\section{Acknowledgments}

This work was supported by Grants from the National Chung Hsing University and Council of Agriculture, Agricultural Research Institute (NCHU-TARI 10106) Taichung, Taiwan, and in part by the Ministry of Education, Taiwan, under the ATU plan. A part of work was supported by STSP Grant EG310815101 (for Ching-Liang Chu).

\section{References}

[1] R. M. Steinman, "Decisions about dendritic cells: past, present, and future," Annual Review of Immunology, vol. 30, pp. 1-22, 2012.

[2] R. A. Hopkins and J. E. Connolly, "The specialized roles of immature and mature dendritic cells in antigen cross-presentation," Immunologic Research, vol. 53, no. 1-3, pp. 91-107, 2012.
[3] C. Hivroz, K. Chemin, M. Tourret, and A. Bohineust, "Crosstalk between T lymphocytes and dendritic cells," Critical Reviews in Immunology, vol. 32, no. 2, pp. 139-155, 2012.

[4] N. Hanke, D. Alizadeh, E. Katsanis, and N. Larmonier, "Dendritic cell tumor killing activity and its potential applications in cancer immunotherapy," Critical Reviews in Immunology, vol. 33, no. 1, pp. 1-21, 2013.

[5] R. M. Roy and B. S. Klein, "Dendritic cells in antifungal immunity and vaccine design," Cell Host \& Microbe, vol. 11, no. 5, pp. 436-446, 2012.

[6] J. A. Hubbell, S. N. Thomas, and M. A. Swartz, "Materials engineering for immunomodulation," Nature, vol. 462, no. 7272, pp. 449-460, 2009.

[7] S. T. Chang, "Overview of mushroom cultivation and utilization as functional foods," in Mushrooms as Functional Foods, P. C. K. Cheung, Ed., pp. 1-33, John Wiley \& Sons, New Jersey, NJ, USA, 2008.

[8] E. Guillamón, A. García-Lafuente, M. Lozano et al., "Edible mushrooms: roles in the prevention of cardiovascular diseases," Fitoterapia, vol. 81, no. 7, pp. 715-723, 2010.

[9] S. Yu, V. Weaver, K. Martin, and M. T. Cantorna, "The effects of whole mushrooms during inflammation," BMC Immunology, vol. 10, article 12, 2009.

[10] U. Lindequist, T. H. J. Niedermeyer, and W.-D. Jülich, "The pharmacological potential of mushrooms," Evidence-Based Complementary and Alternative Medicine, vol. 2, no. 3, pp. 285299, 2005.

[11] H.-Y. Hsu, K.-F. Hua, C.-C. Lin, C.-H. Lin, J. Hsu, and C.H. Wong, "Extract of Reishi polysaccharides induces cytokine expression via TLR4-modulated protein kinase signaling pathways," Journal of Immunology, vol. 173, no. 10, pp. 5989-5999, 2004.

[12] J.-L. Ko, C.-I. Hsu, R.-H. Lin, C.-L. Kao, and J.-Y. Lin, "A new fungal immunomodulatory protein, FIP-fve isolated from the edible mushroom, Flammulina velutipes and its complete amino acid sequence," European Journal of Biochemistry, vol. 228, no. 2, pp. 244-249, 1995.

[13] L. Barros, B. A. Venturini, P. Baptista, L. M. Estevinho, and I. C. F. R. Ferreira, "Chemical composition and biological properties of Portuguese wild mushrooms: a comprehensive study," Journal of Agricultural and Food Chemistry, vol. 56, no. 10, pp. 3856-3862, 2008.

[14] J.-T. Chen and J.-W. Huang, "Control of plant diseases with secondary metabolite of Clitocybe nuda," New Biotechnology, vol. 26, no. 3-4, pp. 193-198, 2009.

[15] J. T. Chen, H. J. Su, and J. W. Huang, "Isolation and identification of secondary metabolites of Clitocybenuda inhibition of zoospore germination of Phytophthoracapsici," Journal of Agricultural and Food Chemistry, vol. 60, no. 30, pp. 7341-7344, 2012.

[16] B. Dulger, C. C. Ergul, and F. Gucin, "Antimicrobial activity of the macrofungus Lepista nuda," Fitoterapia, vol. 73, no. 7-8, pp. 695-697, 2002.

[17] N. Mercan, M. E. Duru, A. Turko Glu, K. Gezer, I. Kivrak, and H. Turko Glu, "Antioxidant and antimicrobial properties of ethanolic extract from Lepista nuda (Bull.) Cooke," Annals of Microbiology, vol. 56, no. 4, pp. 339-344, 2006.

[18] M. A. Murcia, M. Martínez-Tomé, A. M. Jiménez, A. M. Vera, M. Honrubia, and P. Parras, "Antioxidant activity of edible fungi (truffles and mushrooms): losses during industrial processing," Journal of Food Protection, vol. 65, no. 10, pp. 1614-1622, 2002. 
[19] K. D. Beattie, R. Ulrich, I. D. Grice et al., "Ethanolic and aqueous extracts derived from Australian fungi inhibit cancer cell growth in vitro," Mycologia, vol. 103, no. 3, pp. 458-465, 2011.

[20] Y. S. Lee, J. Y. Han, E. Y. Joo, S. R. Shin, and N. W. Kim, "Study on the anti-tumor effects of extracts from Lepistanuda mushroom," Journal of the Korean Society of Food Science and Nutrition, vol. 34, no. 3, pp. 317-322, 2005.

[21] Y. Y. Wu, H. X. Wang, and T. B. Ng, "A Novel Metalloprotease from the Wild Basidiomycete Mushroom Lepista Nuda," Journal of Microbiology and Biotechnology, vol. 21, no. 3, pp. 256262, 2011.

[22] C.-C. Lin, C.-W. Chou, A.-L. Shiau et al., "Therapeutic HER2/ Neu DNA vaccine inhibits mouse tumor naturally overexpressing endogenous neu," Molecular Therapy, vol. 10, no. 2, pp. 290301, 2004.

[23] S.-T. Wang, C.-C. Chang, M.-C. Yen et al., "RNA interferencemediated silencing of Foxo3 in antigen-presenting cells as a strategy for the enhancement of DNA vaccine potency," Gene Therapy, vol. 18, no. 4, pp. 372-383, 2011.

[24] C.-C. Lin, Y.-L. Yu, C.-C. Shih et al., "A novel adjuvant Ling Zhi8 enhances the efficacy of DNA cancer vaccine by activating dendritic cells," Cancer Immunology, Immunotherapy, vol. 60, no. 7, pp. 1019-1027, 2011.

[25] G.-Y. Kim, M.-G. Han, Y.-S. Song et al., "Proteoglycan isolated from Phellinus linteus induces toll-like receptors 2- and 4-mediated maturation of murine dendritic cells via activation of ERK, p38, and NF- $\kappa$ B," Biological and Pharmaceutical Bulletin, vol. 27, no. 10, pp. 1656-1662, 2004.

[26] C.-H. Huang, C.-C. Chang, C.-M. Lin et al., "Promoting effect of Antrodia camphorata as an immunomodulating adjuvant on the antitumor efficacy of HER-2/neu DNA vaccine," Cancer Immunology, Immunotherapy, vol. 59, no. 8, pp. 1259-1272, 2010.

[27] R. Rezzani, L. Rodella, G. Zauli, L. Caimi, and M. Vitale, "Mouse peritoneal cells as a reservoir of late dendritic cell progenitors," British Journal of Haematology, vol. 104, no. 1, pp. 111-118, 1999.

[28] J.-F. Arrighi, M. Rebsamen, F. Rousset, V. Kindler, and C. Hauser, "A critical role for p38 mitogen-activated protein kinase in the maturation of human blood-derived dendritic cells induced by lipopolysaccharide, TNF- $\alpha$, and contact sensitizers," Journal of Immunology, vol. 166, no. 6, pp. 3837-3845, 2001.

[29] H. An, Y. Yu, M. Zhang et al., "Involvement of ERK, p38 and NF- $\kappa$ B signal transduction in regulation of TLR2, TLR4 and TLR9 gene expression induced by lipopolysaccharide in mouse dendritic cells," Immunology, vol. 106, no. 1, pp. 38-45, 2002.

[30] H. Lu, Y. Yang, E. Gad et al., "Polysaccharide krestin is a novel TLR2 agonist that mediates inhibition of tumor growth via stimulation of CD8 T cells and NK cells," Clinical Cancer Research, vol. 17, no. 1, pp. 67-76, 2011.

[31] H. S. Kim, J. Y. Kim, J. S. Kang et al., "Cordlan polysaccharide isolated from mushroom Cordyceps militaris induces dendritic cell maturation through toll-like receptor 4 signalings," Food and Chemical Toxicology, vol. 48, no. 7, pp. 1926-1933, 2010.

[32] C.-F. Tu, C.-C. Lin, M.-C. Chen et al., "Autologous neu DNA vaccine can be as effective as xenogenic neu DNA vaccine by altering administration route," Vaccine, vol. 25, no. 4, pp. 719728, 2007.

[33] C.-C. Lin, C.-F. Tu, M.-C. Yen et al., "Inhibitor of heat-shock protein 90 enhances the antitumor effect of DNA vaccine targeting clients of heat-shock protein," Molecular Therapy, vol. 15, no. 2, pp. 404-410, 2007.
[34] J. Zhu, H. Yamane, and W. E. Paul, "Differentiation of effector $\mathrm{CD} 4^{+} \mathrm{T}$ cell populations," Annual Review of Immunology, vol. 28, pp. 445-489, 2010.

[35] W. T. Watford, M. Moriguchi, A. Morinobu, and J. J. O'Shea, "The biology of IL-12: coordinating innate and adaptive immune responses," Cytokine and Growth Factor Reviews, vol. 14, no. 5, pp. 361-368, 2003.

[36] K. Schroder, P. J. Hertzog, T. Ravasi, and D. A. Hume, "Interferon- $\gamma$ : an overview of signals, mechanisms and functions," Journal of Leukocyte Biology, vol. 75, no. 2, pp. 163-189, 2004.

[37] H. Park, Z. Li, X. O. Yang et al., "A distinct lineage of CD4 T cells regulates tissue inflammation by producing interleukin 17," Nature Immunology, vol. 6, no. 11, pp. 1133-1141, 2005.

[38] G. Chamilos, D. Ganguly, R. Lande et al., "Generation of IL23 producing Dendritic Cells (DCs) by airborne fungi regulates fungal pathogenicity via the induction of TH-17 responses," PLoS ONE, vol. 5, no. 9, Article ID e12955, 2010.

[39] M. Fei, T. Oriss, C. Steele, J. Kolls, P. Ray, and A. Ray, "Aspergillus fumigatus primes dendritic cells to stimulate IL-17 production from CD4 $4^{+}$T cells," The FASEB Journal, vol. 22, p. 677, 2008.

[40] H. Yoshida, M. Suzuki, R. Sakaguchi et al., "Preferential induction of Th17 cells in vitro and in vivo by Fucogalactan from Ganoderma lucidum (Reishi)," Biochemical and Biophysical Research Communications, vol. 422, no. 1, pp. 174-180, 2012.

[41] E. M. Carmona, T. J. Kottom, D. M. Hebrink et al., "Glycosphingolipids mediate pneumocystis cell wall $\beta$-glucan activation of the IL-23/IL-17 axis in human dendritic cells," American Journal of Respiratory Cell and Molecular Biology, vol. 47, no. 1, pp. 5059, 2012.

[42] D. M. Roeleveld, A. E. van Nieuwenhuijze, W. B. van den Berg, and M. I. Koenders, "The Th17 pathway as a therapeutic target in rheumatoid arthritis and other autoimmune and inflammatory disorders," BioDrugs, 2013.

[43] A. Ambrosi, A. Espinosa, and M. Wahren-Herlenius, "IL-17: a new actor in IFN-driven systemic autoimmune diseases," European Journal of Immunology, vol. 42, no. 9, pp. 2274-2284, 2012.

[44] L. Yang, D. E. Anderson, C. Baecher-Allan et al., "IL-21 and TGF- $\beta$ are required for differentiation of human T H17 cells," Nature, vol. 454, no. 7202, pp. 350-352, 2008.

[45] K. Hirahara, K. Ghoreschi, A. Laurence, X.-P. Yang, Y. Kanno, and J. J. O'Shea, "Signal transduction pathways and transcriptional regulation in Th17 cell differentiation," Cytokine and Growth Factor Reviews, vol. 21, no. 6, pp. 425-434, 2010.

[46] T. A. Libermann and D. Baltimore, "Activation of interleukin6 gene expression through the NF- $\kappa \mathrm{B}$ transcription factor," Molecular and Cellular Biology, vol. 10, no. 5, pp. 2327-2334, 1990.

[47] T. L. Murphy, M. G. Cleveland, P. Kulesza, J. Magram, and K. M. Murphy, "Regulation of interleukin 12 p40 expression through an NF- $\kappa$ B half-site," Molecular and Cellular Biology, vol. 15, no. 10, pp. 5258-5267, 1995.

[48] M. A. Collart, P. Baeuerle, and P. Vassalli, "Regulation of tumor necrosis factor alpha transcription in macrophages: involvement of four $\kappa \mathrm{B}$-like motifs and of constitutive and inducible forms of NF- $\kappa \mathrm{B}$," Molecular and Cellular Biology, vol. 10, no. 4, pp. 1498-1506, 1990.

[49] M. Hinz, P. Löser, S. Mathas, D. Krappmann, B. Dörken, and C. Scheidereit, "Constitutive NF- $\kappa \mathrm{B}$ maintains high expression of a characteristic gene network, including CD40, CD86, and a set of antiapoptotic genes in Hodgkin/Reed-Sternberg cells," Blood, vol. 97, no. 9, pp. 2798-2807, 2001. 
[50] G.-M. Zou and W.-Y. Hu, "LIGHT regulates CD86 expression on dendritic cells through NF- $\kappa$ B, but not JNK/AP-1 signal transduction pathway," Journal of Cellular Physiology, vol. 205, no. 3, pp. 437-443, 2005.

[51] Y.-L. Lin, Y.-C. Liang, S.-S. Lee, and B.-L. Chiang, "Polysaccharide purified from Ganoderma lucidum induced activation and maturation of human monocyte-derived dendritic cells by the NF- $\kappa$ B and p38 mitogen-activated protein kinase pathways," Journal of Leukocyte Biology, vol. 78, no. 2, pp. 533-543, 2005.

[52] P. M. Boggiatto, F. Jie, M. Ghosh et al., "Altered dendritic cell phenotype in response to Leishmania amazonensis amastigote infection is mediated by MAP kinase, ERK," American Journal of Pathology, vol. 174, no. 5, pp. 1818-1826, 2009.

[53] T. Nakahara, H. Uchi, K. Urabe, Q. Chen, M. Furue, and Y. Moroi, "Role of c-Jun N-terminal kinase on lipopolysaccharide induced maturation of human monocyte-derived dendritic cells," International Immunology, vol. 16, no. 12, pp. 1701-1709, 2004.

[54] M. Yamashita, R. Shinnakasu, H. Asou et al., "Ras-ERK MAPK cascade regulates GATA3 stability and Th2 differentiation through ubiquitin-proteasome pathway," Journal of Biological Chemistry, vol. 280, no. 33, pp. 29409-29419, 2005.

[55] T. Nakahara, Y. Moroi, H. Uchi, and M. Furue, "Differential role of MAPK signaling in human dendritic cell maturation and Th1/Th2 engagement," Journal of Dermatological Science, vol. 42, no. 1, pp. 1-11, 2006.

[56] T. Kaisho and S. Akira, "Dendritic-cell function in Toll-like receptor- and MyD88-knockout mice," Trends in Immunology, vol. 22, no. 2, pp. 78-83, 2001.

[57] D. Yamanaka, M. Motoi, K. Ishibashi, N. N. Miura, Y. Adachi, and N. Ohno, "Effect of Agaricusbrasiliensis-derived cold water extract on Toll-like receptor 2-dependent cytokine production in vitro," Immunopharmacology and Immunotoxicology, vol. 34, no. 4, pp. 561-570, 2012.

[58] H. S. Kim, J. T. Hong, Y. Kim, and S. B. Han, "Stimulatory effect of $\beta$-glucans on immune cells," Immune Network, vol. 11, no. 4, pp. 191-195, 2011.

[59] S. L. Weinstein, C. H. June, and A. L. DeFranco, "Lipopolysaccharide-induced protein tyrosine phosphorylation in human macrophages is mediated by CD14," Journal of Immunology, vol. 151, no. 7, pp. 3829-3838, 1993.

[60] S. Akira, S. Uematsu, and O. Takeuchi, "Pathogen recognition and innate immunity," Cell, vol. 124, no. 4, pp. 783-801, 2006.

[61] J. Rice, C. H. Ottensmeier, and F. K. Stevenson, "DNA vaccines: precision tools for activating effective immunity against cancer," Nature Reviews Cancer, vol. 8, no. 2, pp. 108-120, 2008.

[62] S. Loisel-Meyer, R. Foley, and J. A. Medin, "Immuno-gene therapy approaches for cancer: from in vitro studies to clinical trials," Frontiers in Bioscience, vol. 13, no. 9, pp. 3202-3214, 2008.

[63] A. M. Bodles-Brakhop and R. Draghia-Akli, "DNA vaccination and gene therapy: optimization and delivery for cancer therapy," Expert Review of Vaccines, vol. 7, no. 7, pp. 1085-1101, 2008.

[64] M. Rinaldi, D. Fioretti, S. Iurescia, and V. M. Fazio, "DNA vaccines: developing new strategies against cancer," Journal of Biomedicine and Biotechnology, vol. 2010, Article ID 174378, 16 pages, 2010. 


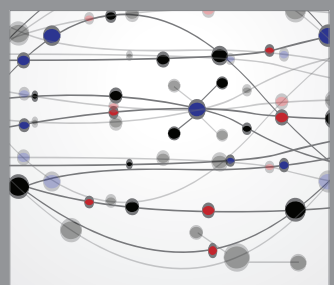

The Scientific World Journal
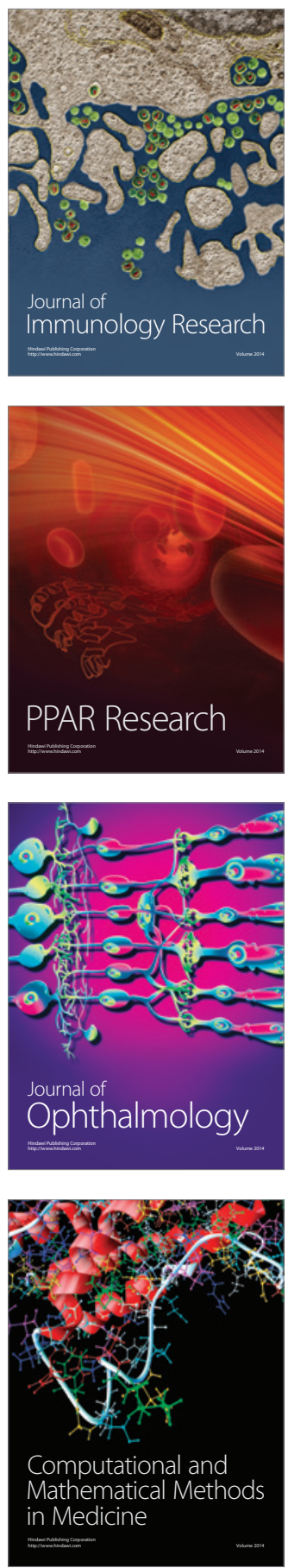

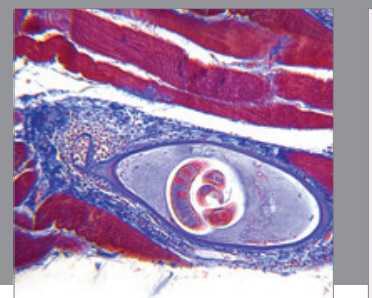

Gastroenterology

Research and Practice
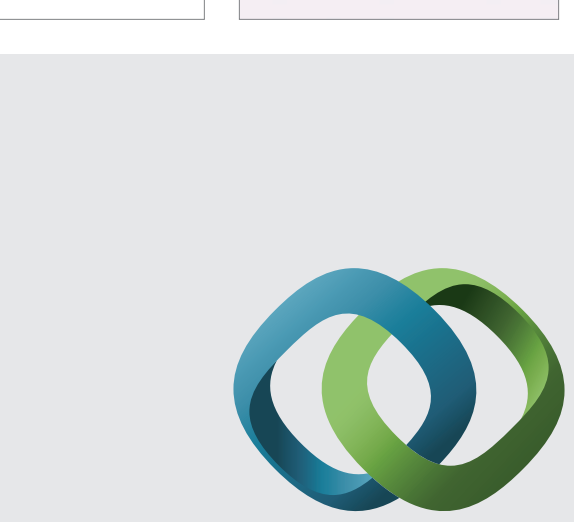

\section{Hindawi}

Submit your manuscripts at

http://www.hindawi.com
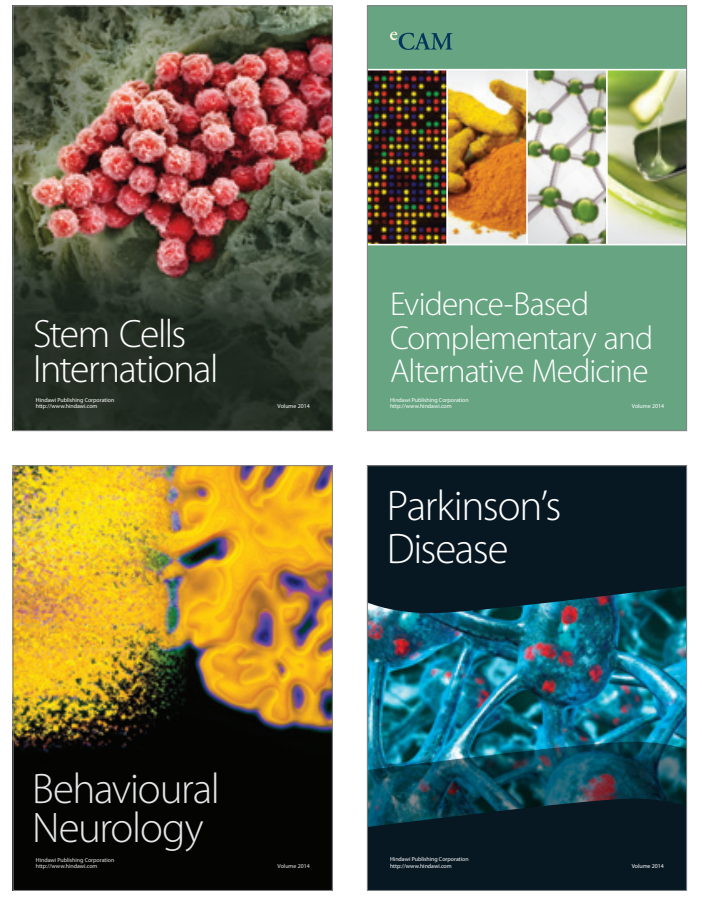
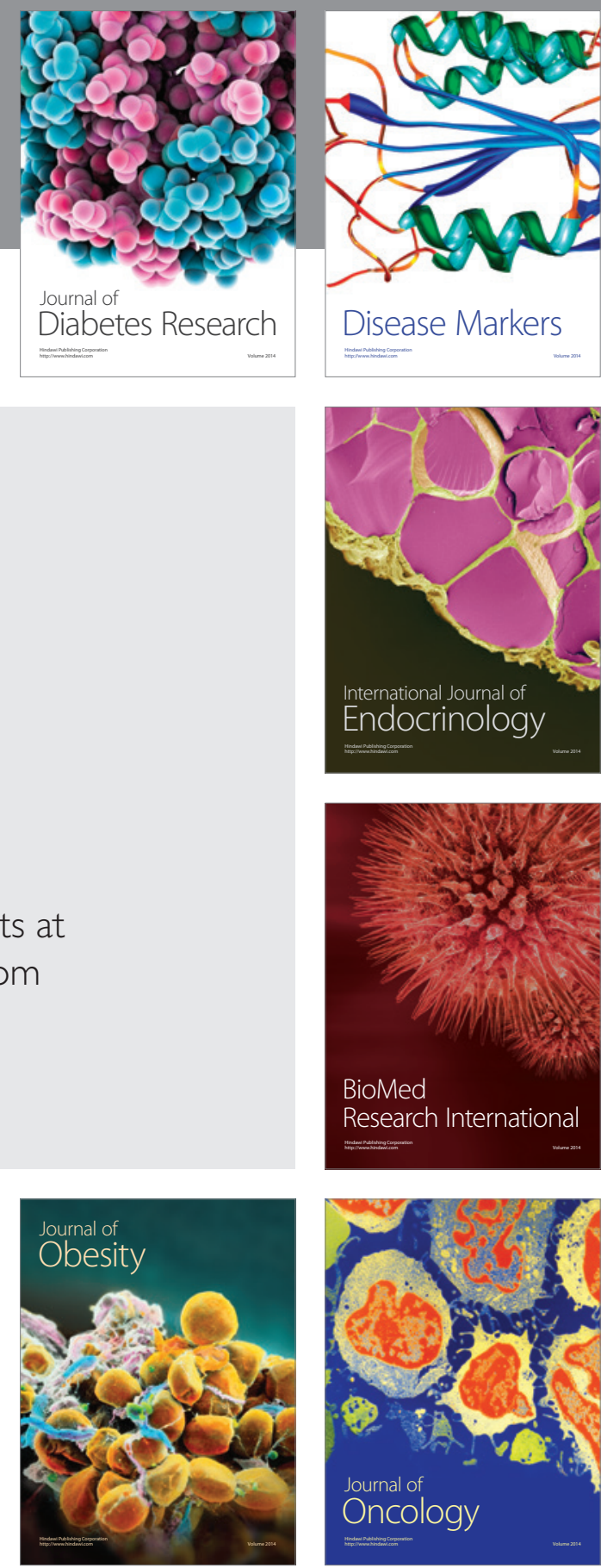

Disease Markers
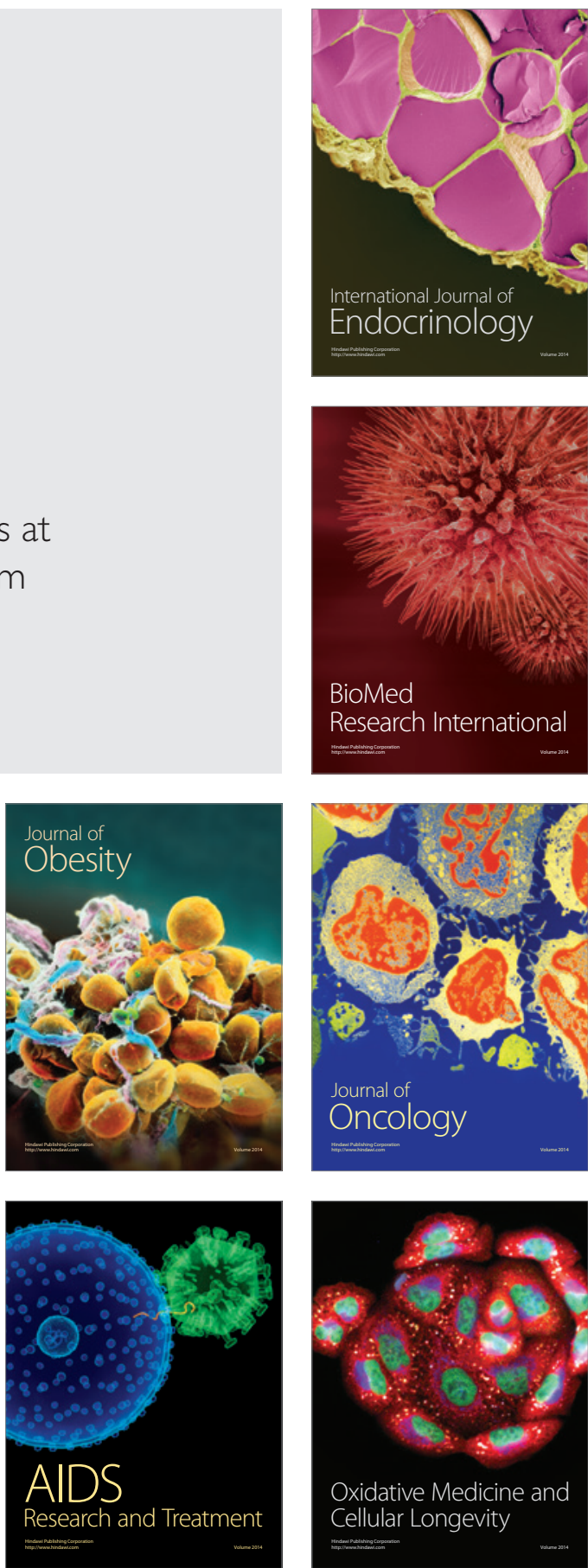